$11-1-2020$

\title{
Evaluating the inclusion of family planning within the National Health Insurance benefits package in Ghana
}

\author{
Kamil Fuseini \\ Population Council \\ Augustine Ankomah \\ Population Council
}

Follow this and additional works at: https://knowledgecommons.popcouncil.org/departments_sbsr-rh

Part of the Health Policy Commons, and the Health Services Research Commons How does access to this work benefit you? Let us know!

\section{Recommended Citation}

Fuseini, Kamil and Augustine Ankomah. 2020. "Evaluating the inclusion of family planning within the National Health Insurance benefits package in Ghana," research report. Washington, DC: Population Council. 


\section{POPUlation \\ - COUNCIL \\ Ideas. Evidence. Impact.}

\section{Evaluating the Inclusion of Family Planning Within the National Health Insurance Benefits Package in Ghana}

Research Report November 2020 



\section{POPUlation \\ COUNCIL \\ Ideas. Evidence. Impact.}

The Population Council confronts critical health and development issues-from stopping the spread of HIV to improving reproductive health and ensuring that young people lead full and productive lives. Through biomedical, social science, and public health research in 50 countries, we work with our partners to deliver solutions that lead to more effective policies, programs, and technologies that improve lives around the world. Established in 1952 and headquartered in New York, the Council is a nongovernmental, nonprofit organization governed by an international board of trustees.

Population Council

H\&C Place, 204 Yiyiwa Drive, Abelemkpe

Accra, Ghana

Digital address: GA-124-5840

Tel: +233 $302780711 / 2$

Fax: +233 302780713

email: info.ghana@popcouncil.org

Mailing Address:

P. O. Box CT 4906

Cantonment

Accra, Ghana

popcouncil.org

The study was conducted in collaboration with the Ministry of Health (MOH), National Health Insurance Authority (NHIA), Ghana Health Service (GHS), and Marie Stope International-Ghana (MSIG).

The Population Council received a grant to evaluate the pilot inclusion of family planning within the National Health Insurance Benefits Package in Ghana from the Bill \& Melinda Gates Foundation. However, the views expressed do not necessarily reflect the official policies of the Foundation.

Acknowledgments: We thank Akua Obeng Dwamena, Leonie A. Allorsey, and Rachel N. Anum for their immense technical support in analyzing and drafting the report.

Suggested citation: Kamil Fuseini \& Augustine Ankomah. 2020. "Evaluating the inclusion of family planning within the National Health Insurance benefits package in Ghana," Research Report. Washington, DC: Population Council. 

CIP

CHPS

CPR

DHIMS

FP

FP-CIP

GDHS

GHS

GoG

LARC

LMIC

$\mathrm{MCPR}$

$M \& E$

$\mathrm{MoH}$

MSI

MSI-G

NHIA

NHIS

OP

PC

$\mathrm{RH}$

TFR

UHC

WIFA

WRA
Costed Implementation Plan

Community-Based Health Planning and Services

Contraceptive Prevalence Rate

District Health Information Management System

Family Planning

Family Planning-Costed Implementation Plan

Ghana Demographic and Health Survey

Ghana Health Service

Government of Ghana

Long-acting Reversible Contraception

Lower Middle-Income Countries

Modern Contraceptive Prevalence Rate

Monitoring and Evaluation

Ministry of Health

Marie Stopes International

Marie Stopes International-Ghana

National Health Insurance Authority

National Health Insurance Scheme

Out-of-Pocket

Population Council

Reproductive Health

Total Fertility Rate

Universal Health Coverage

Women in Fertility Age

Women of Reproductive Age 


\section{Background}

Contraceptive use in Ghana has remained low despite its annual increase since 2012. The annual increase has not been commensurate with the improvement in economic indicators and the decline in total fertility rate (TFR) within the same period as anticipated. Having a high unmet need for family planning (FP) (30\% of married women and $40 \%$ of unmarried sexually active women) suggests that there may be barriers to access and uptake of FP. Over time, several policies, including Ghana's Costed Implementation Plan (CIP) from 2015 through 2020 have suggested several FP initiatives to improve contraceptive use yet they have not been entirely implemented. Further, although FP was included in the health insurance act passed in 2003 (Act 650), amended in 2008 (Act 753), and revised in 2012 (Act 852), which indicated that healthcare benefits include FP, people continue to pay out of pocket for FP services at National Health Insurance Authority (NHIA) credentialled facilities because the policy is yet to be implemented. In some settings, evidence suggests an increase in contraceptive uptake with the implementation of the removal of out-of-pocket (OP) costs for FP services, therefore, embedding an FP package into Ghana's national health insurance scheme may increase uptake of FP service and method mix and improve health outcomes.

\section{Objectives}

The main objective of this study was to assess the impact of the FP Pilot intervention(s), namely OP cost removal for FP services, demand generation for FP, and provider training on long-acting reversible contraceptives (LARCs) service provision on FP service uptake. Specifically, the study investigated:

i. The impact of the FP Pilot intervention(s) on the total number of new FP acceptors.

ii. The impact of the FP Pilot intervention(s) on method-specific new FP acceptors.

\section{Methods}

The study employed a quasi-experimental time-series design. The overall study period was from January 2017 to February 2020 split into two phases: pre-intervention (January 2017 to April 2018), and intervention period (May 2018 to February 2020). The study used monthly FP service data from Ghana Health Service's District Health Information System (DHIMS) for the assessment. Three different interventions were implemented-OP cost removal for FP services, demand generation for FP, and provider training on long-acting reversible contraceptives (LARCs) in the selected districts. The control districts were selected based on their similarity to the intervention districts. Statistical analysis was carried out by running controlled interrupted time series (ITS) models to assess the impact of the different combinations of the interventions on total new FP service uptake and method-specific uptake. 


\section{Key findings}

Impact of out-of-pocket cost removal for FP services and other interventions on uptake of FP and method mix (all seven intervention districts with OP cost removal)

The difference in the number of new FP acceptors between intervention and control districts in the first month of the intervention suggests a positive impact of the intervention (but not statistically significant). Further, it was observed that pre-intervention, the total number of FP acceptors in both the intervention and control districts were on the decline. However, during the intervention period, the rate of increase in new FP acceptors in the intervention districts trended higher compared to the control districts, but the differences were not statistically significant. There was a statistically significant monthly increase in new IUD acceptors throughout the intervention period in the intervention districts compared with that of the control districts. Further, there was evidence that during the intervention period, the intervention districts saw an increase in the number of new IUD acceptors per month compared with the control districts where new IUD acceptors per month decreased significantly over the same period. During the intervention period, new oral contraceptive acceptors in both the intervention and control districts were on the decline but not statistically significant.

\section{Impact of out-of-pocket cost removal for FP services only on uptake of FP and method mix}

Prior to the intervention (out-of-pocket cost removal for FP services only), the number of new FP acceptors was on a downward trend in both the intervention and control districts. However, the impact of the intervention in the first month was positive, although not statistically significant. Throughout the intervention period, new FP acceptors appeared to be increasing in the intervention districts and decreasing in the control districts, although neither was statistically significant. There was evidence that during the intervention period the intervention districts increased in the number of new IUD acceptors. However, in the control districts, the number of new IUD acceptors per month trended towards a decrease. Also, it was observed that during the intervention period, the number of new oral contraceptive acceptors in both the intervention and control districts was on the decline although not statistically significant.

Impact of out-of-pocket cost removal of FP services, demand generation, and LARC training on uptake of FP and method mix

The number of new FP acceptors in the intervention district significantly increased during the intervention period. However, the increase in the control district, during the same period was not statistically significant. With respect to IUD acceptors, there was a statistically significant increase in the before- and during the intervention period trends in the intervention district compared with the control district. After the introduction of the intervention, new IUD acceptors in the intervention district increased monthly. Conversely, the results showed that the number of new oral contraceptive acceptors in the intervention and control districts trended downwards throughout the intervention period.

\section{Impact of out-of-pocket cost removal for FP services and LARC training (without demand generation) on uptake of FP and method mix}

There was a statistically significant positive effect of the intervention during the first month. The results also showed that after the first month, the number of new FP acceptors 
in the intervention district trended downwards, which was similar in the control district although not statistically significant. For new IUD acceptors, there was limited evidence that the intervention district was different from the control district pre-intervention and in the first month of the intervention and similar results were found concerning oral contraceptive acceptors.

\section{Key recommendations}

Based on the findings of the study, the following recommendations are made:

- The Ministry of Health in collaboration with the National Health Insurance Authority and Ghana Health Service should strongly consider implementing the OP cost removal for FP services as it increases the uptake of FP and method mix based on the positive effect of OP cost removal for FP services on the number of new FP acceptors and LARCs acceptors.

- The minimum package for the scale-up should be OP cost removal for FP services plus demand generation activities based on the statistically significant effect of OP cost removal for FP services on the number of new FP acceptors and LARCs acceptors.

- The Ministry of Health in collaboration with the National Health Insurance Authority and Ghana Health Service should consider undertaking a needs assessment regarding the capacity building of health providers for the provision of LARCs as the findings showed an increase in the use of LARCs before scale-up.

- The Ministry of Health and Ghana Health Service should ensure FP commodity security especially LARCs as there was evidence of an increase in LARCs acceptors. 


\section{TABLE OF CONTENTS}

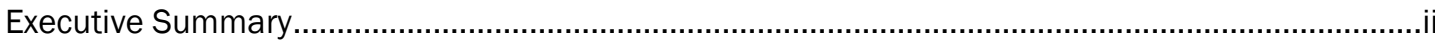

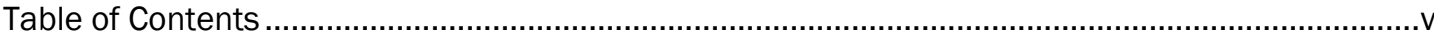

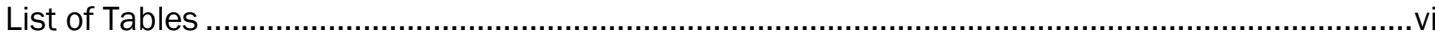

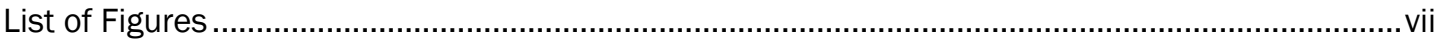

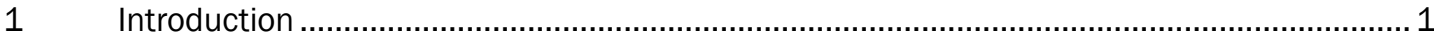

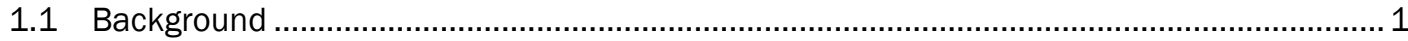

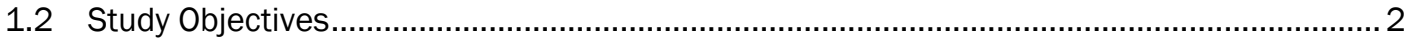

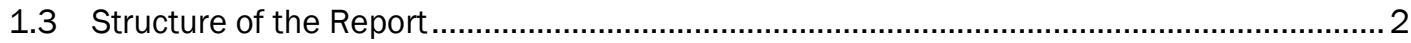

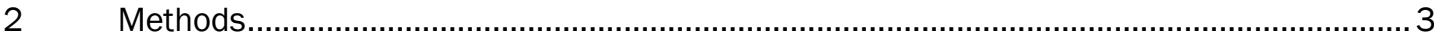

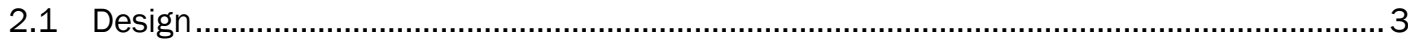

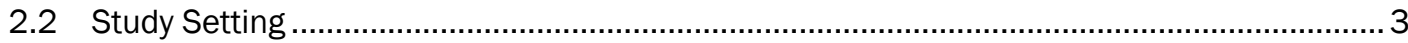

2.3 Selection of Study Districts ............................................................................................... 4

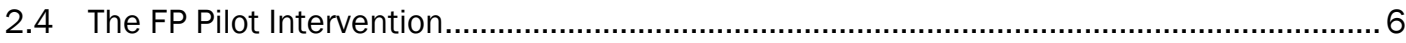

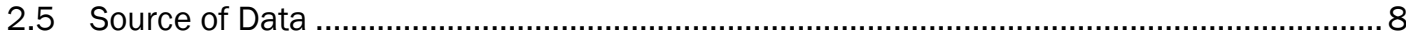

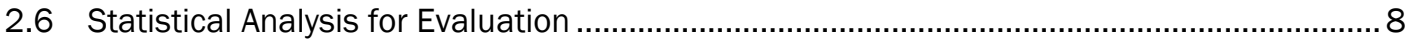

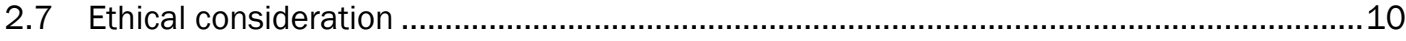

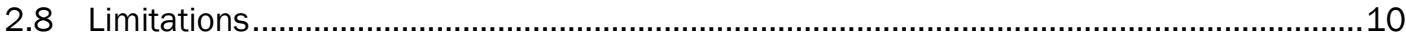

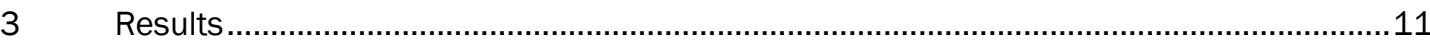

3.1 Impact of Out-of-Pocket Cost Removal for FP Services and Any Other Intervention on Uptake of FP and Method Mix (All Seven Intervention Districts) ................................................12

3.2 Impact of Out-of-Pocket Cost Removal for FP Services Only on Uptake of FP and Method Mix (Five Intervention Districts) ............................................................................................ 18

3.3 Impact of Out of Pocket Cost Removal for FP Services, Demand Generation, LARC Training

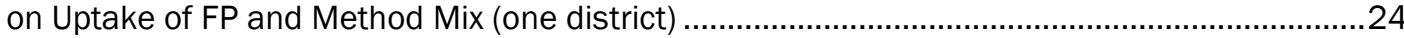

3.4 Impact of Out of Pocket Cost Removal for FP Services and LARCs Training on Uptake of FP

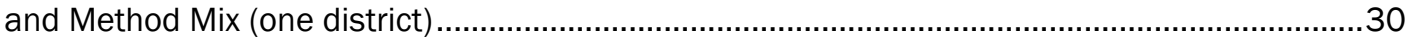

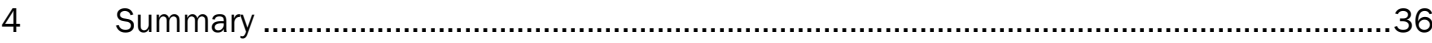

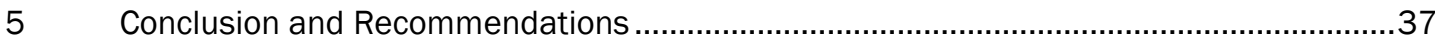

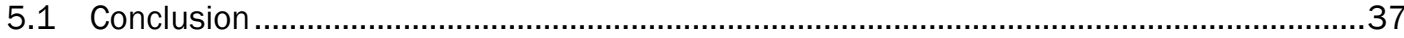

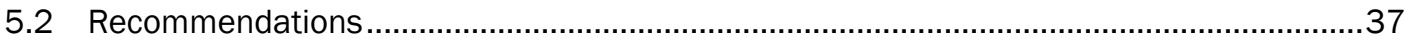




\section{LIST OF TABLES}

TABLE 1: Matched FP Pilot intervention and control districts - 5

TABLE 2: Roles of stakeholders in the FP Pilot Project 6

TABLE 3: Interventions implemented in the nine FP Pilot intervention districts

TABLE 4: Number of CHNs and Midwives Training Needs Gap

TABLE 5: ITS parameter estimates for monthly new FP acceptors - seven intervention and control districts - 13

TABLE 6: ITS parameter estimates for monthly new FP acceptors - seven intervention and control districts -

TABLE 7: ITS parameter estimates for monthly new FP acceptors - seven intervention and control districts

TABLE 8: ITS parameter estimates for monthly new monthly new FP acceptors - five intervention and control districts

TABLE 9: ITS parameter estimates for monthly new FP acceptors - five intervention and control districts

TABLE 10: ITS parameter estimates for monthly new FP acceptors - five intervention and control districts

TABLE 11: ITS parameter estimates for monthly new FP acceptors - one district-ב-ב-ב-ב-ב-ב-ב-25

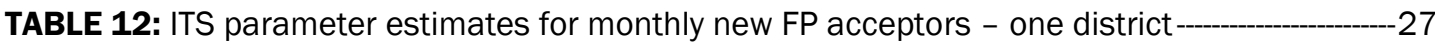

TABLE 13: ITS parameter estimates for monthly new FP acceptors - one district-_-_-_-_-_---29

TABLE 14: ITS parameter estimates for monthly new FP acceptors - one district --------------------31

TABLE 15: Parameter estimates for monthly new FP acceptors - one district

TABLE 16: Parameter estimates for monthly new FP acceptors - one district - 


\section{LIST OF FIGURES}

FIGURE 1: Map of study regions 3

FIGURE 2: Trends in new FP acceptors (January 2017 - February 2020)

FIGURE 3: Trends in new IUD acceptors (January 2017 - February 2020) -

FIGURE 4: Trends in new implant acceptors (January 2017 - February 2020) -

FIGURE 5: Trends in new injectable acceptors (January 2017 - February 2020)-_-_-_16

FIGURE 6: Trends in new oral contraceptive acceptors (January 2017 - February 2020)---_---16

FIGURE 7: Trends in new FP acceptors (January 2017 - February 2020)-_-18

FIGURE 8: Trends in new IUD acceptors (January 2017 - February 2020) -

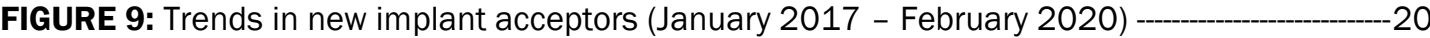

FIGURE 10: Trends in new Injectable acceptors (January 2017 - February 2020) -------י------22

FIGURE 11: Trends in new oral contraceptive acceptors (January 2017 - February 2020)--------22

FIGURE 12: Trends in new FP acceptors (January 2017 - February 2020)--_-24

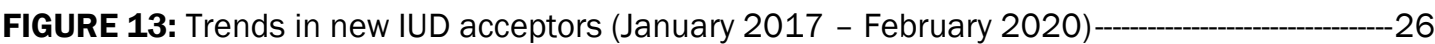

FIGURE 14: Trends in new implant acceptors (January 2017 - February 2020)

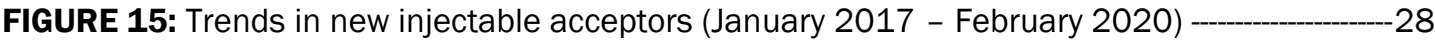

FIGURE 16: Trends in oral contraceptive acceptors (January 2017 - February 2020)---_-_-_-_---28

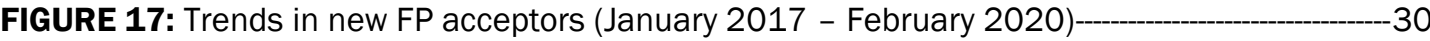

FIGURE 18: Trends in new IUD acceptors (January 2017 - February 2020)-_-32

FIGURE 19: Trends in new implant acceptors (January 2017 - February 2020)

FIGURE 20: Trends in new injectable acceptors (January 2017 - February 2020) -____-_-34

FIGURE 21: Trends in new oral contraceptive acceptors (January 2017 - February 2020)--------34 



\subsection{Background}

Although the rate of increase for contraceptive use in Ghana has grown at about three percent annually since $2012^{1}$, use rates remain lower than expected. Unmet need for family planning (FP) remains high-30 percent of married and 42 percent of unmarried sexually active women who want to avoid or delay pregnancy are not using FP2,3. To reduce unmet need for FP, Ghana's Costed Implementation Plan (CIP) for 2015 through 2020 recommended several FP interventions, including removal of direct cost barriers to FP services to improve access. If the CIP recommendations had been fully implemented, more than 2.3 million unintended pregnancies, 800,000 abortions, and 5,000 maternal deaths between 2016 and 2020 could have been averted 4 . The burden of unintended pregnancies, unsafe abortion, and maternal mortality fall most heavily on disadvantaged populations such as adolescents, the poor, and rural residents ${ }^{5,6}$.

Out-of-pocket (OP) costs for FP, particularly for long-acting reversible contraceptives (LARCs), can be a barrier to voluntary contraceptive uptake in high-, middle-, and lowincome countries. Evidence from studies of community-based programs that target subsidies (e.g., vouchers) to potential FP clients have generally found an increase in FP use $\mathrm{P}^{7,8,9,10}$. Evidence of the magnitude of OP payments is clear from the 2018 Commodity Gap Analysis commissioned by the Reproductive Health Supplies Coalition, which reported that 80 percent of annual commodity costs in 135 low- and middle-income countries (LMICs) were borne by consumers who bought FP supplies in the private sector ${ }^{11}$. Subsidies, such as vouchers and health insurance, are often associated with lower OP expenses for individuals accessing FP services, and the evidence suggest that these strategies may accelerate gains in contraceptive prevalence and progress towards universal health coverage $(\mathrm{UHC})^{8,12,13}$. Embedding an FP package into national health insurance may improve uptake of FP services.

In Ghana, the National Health Insurance Act was passed in 2003 (Act 650), amended in 2008 (Act 753), and revised in 2012 (Act 852), which indicated that healthcare benefits include FP. The expectation was that about 800,000 women would be eligible to benefit from FP inclusion in the National Health Insurance Scheme (NHIS) ${ }^{14}$. Although FP was

\footnotetext{
Ahmed S, Choi Y, Rimon JG, Alzouma S, Gichangi P, Guiella G, et al. 2019. Trends in contraceptive prevalence rates in sub-Saharan Africa since the 2012 London Summit on Family Planning: Results from repeated cross-sectional surveys. Lancet Glob Heal 19: 1-8. https://linkinghub.elsevier.com/retrieve/pii/S2214109X19302001

Ghana Statistical Service, Ghana Health Service, ICF International. Ghana Health and Demographic Survey 2014. Rockville, Maryland, USA.

Ghana Statistical Service, Ghana Health Service, ICF. Ghana Maternal Health Survey 2017. The DHS Program: Rockville, Maryland, USA; 2018.

Government of Ghana. 2015. Accra: Ghana Health Service. 2015. Washington, DC: Futures Group, Health Policy Project. Ghana Family Planning Costed Implementation Plan. www.familyplanning2020.org/sites/default/files/Ghana-Family-Planning-CIP-2016-2020.pdf

Ortayli N, Malarcher S. 2010. Equity Analysis: Identifying Who Benefits from Family Planning Programs. Stud Fam Plan 41(2): 101-108.

Ahmed S, Li Q, Liu L, Tsui AO. 2012. Maternal deaths averted by contraceptive use: an analysis of 172 countries. Lancet 380(9837): 111-125. www.sciencedirect.com/science/article/pii/S0140673612604784

Secura GM, Allsworth JE, Madden T, Mullersman JL, Peipert JF. 2010. The contraceptive CHOICE project: Reducing barriers to long-acting reversible contraception. Am J Obs Gynecol 203(2).

8 Bellows B, Bulaya C, Inambwae S, Lissner CL, Ali M, Bajracharya A. 2016. Family Planning Vouchers in Low and Middle Income Countries: A Systematic Review. Stud Fam Plan 47(4): 357-370.

www.researchgate.net/publication/310773977_Family_Planning_Vouchers_in_Low_and_Middle_Income_Countries_A_Systematic_Review

9 Goldin Evans M, Broyles S, Frederiksen B, Gee RE, Phillippi S, Sothern M, et al. 2019. Long-Acting Reversible Contraceptive Utilization After Policy Change Increasing Device Reimbursement to Wholesale Acquisition Cost in Louisiana. Am J Obstet Gynecol. https://linkinghub.elsevier.com/retrieve/pii/S0002937819305897

10 Eisenberg D, McNicholas C, Peipert J. 2013. Cost as a Barrier to Long-Acting Reversible Contraceptive Use in Adolescents. J Adoles Health 52 (4): S59-S63.

11 Reproductive Health Supplies Coalition. 2018. Global Contraceptive Commodity Gap Analysis 2018. Brussels.

12 Bellows B, Mackay A, Dingle A, Tuyiragize R, Nnyombi W. 2017. Increasing Contraceptive Access for Hard-to-Reach Populations with Vouchers and Social Franchising in Uganda. Glob Heal Sci Pract 5(3): 446-455. https://doi.org/10.9745/GHSP-D-17-00065

13 Ross R, Fagan T, Dutta A. 2018. Is health insurance coverage associated with improved family planning access? A Review of Household Survey Data from Seven FP2020 Countries.

${ }^{14}$ FP2020. www.familyplanning2020.org/resources/advocacy-country-spotlight-ghana
} 
included in the health insurance Act, people continue to pay for FP products and services at NHIA-credentialled facilities because the policy is yet to be implemented in practice.

Under the leadership of the Ministry of Health $(\mathrm{MOH})$, the National Health Insurance Authority (NHIA) in collaboration with the Ghana Health Service (GHS), Marie Stopes International-Ghana (MSIG), and Population Council (the Council) started implementing a pilot project to remove FP service OP cost. Under this pilot, all modern clinical FP methods (e.g., injectable, implant, IUD, and sterilization) were added to the National Health Insurance Scheme (NHIS) and expensed by facilities through the claims process. This study seeks to assess the impact of the FP Pilot intervention on the uptake of FP services.

\subsection{Study Objectives}

The main objective of this study was to assess the impact of the FP Pilot intervention(s), namely OP cost removal for FP services, demand generation for FP, and training on longacting reversible contraceptives (LARCs) methods on FP service uptake. Specifically, the study investigated:

i. The impact of the FP Pilot intervention(s) on the total number of new FP acceptors; and

ii. The impact of the FP Pilot intervention(s) on method-specific (IUDs, implants, injectables, and oral contraceptives ${ }^{15}$ ) new FP acceptors.

\subsection{Structure of the Report}

The report is organized into four chapters. The introductory section (Chapter 1) presents background information on the subject area, the problem of OP cost being a barrier to low uptake of FP in LMICs as well as the importance of embedding an FP package into national health insurance. The chapter also highlights the objectives of this study.

Chapter 2 outlines the methods used for the evaluation of the FP Pilot intervention. The study design, the research setting (intervention and control districts), procedures used to select study control districts, source of data, statistical analysis, and ethical guidelines are presented in this chapter.

Chapter 3 presents the results on the impact of various combinations of the interventions on FP service uptake between January 2017 and February 2020 in the various study districts. The impact of OP cost removal for FP services and other interventions (all districts with OP cost removal for FP services) on uptake of FP services and method mix is first presented. Secondly, the impact of OP cost removal for FP services on uptake of FP and method mix is presented. Thirdly, the impact of OP cost removal for FP services, demand generation for FP services, and provider training on LARCs on uptake of FP services and method mix is outlined. Lastly, the impact of OP cost removal for FP services and provider training on LARCs on uptake and method mix are also presented.

Chapter 4 presents the summary of findings and Chapter 5 presents the conclusions and recommendations of the study.

15 The FP Pilot intervention did include oral contraceptives, however, it is anticipated that the FP Pilot intervention activities (i.e., awareness creation activities, demand generation, and provider training can influence the uptake of other FP methods such as oral contraceptives) 


\subsection{Design}

A quasi-experimental times series design, using monthly FP service data from January 2018 to February 2020, was employed. The quasi-experimental times series design takes the form:
Intervention Group
Control Group

$\underset{\mathrm{O}_{1} \mathrm{O}_{2} \mathrm{O}_{3}-\mathrm{O}_{4} \mathrm{O}_{5} \mathrm{O}_{6}}{\stackrel{\mathrm{O}_{1} \mathrm{O}_{2} \mathrm{O}_{3} \times \mathrm{O}_{4} \mathrm{O}_{5} \mathrm{O}_{6}}{\longrightarrow}}$

Where:

$\longrightarrow$ Time

0 An observation measurement, the subscript is used to distinguish one observation measurement from another.

X Intervention(s) (i.e., the OP cost removal for FP services only intervention)

No intervention

\subsection{Study Setting}

This analysis was conducted for nine selected intervention and nine control districts in the four FP Pilot intervention regions: Upper East, Ashanti, Central, and Volta (see Figure 1).

FIGURE 1: Map of study regions

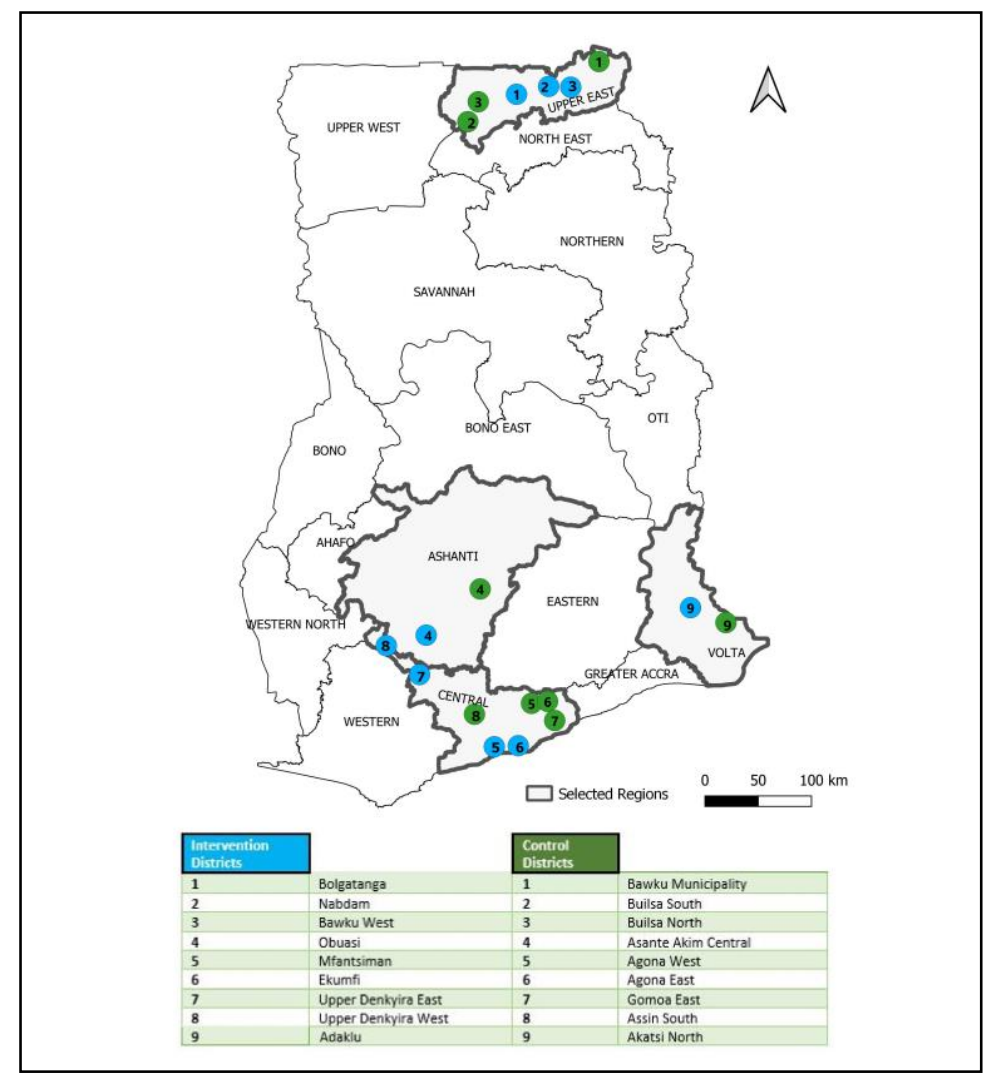




\subsection{Selection of Study Districts}

To reduce threats to validity, the control and intervention districts were as comparable as possible based on the following criteria:

i. The intervention and control districts were in the same region but not contiguous;

ii. The proportions of rural localities within the intervention and control districts were comparable;

iii. The structures of health facilities providing FP services in the intervention and control areas were similar, e.g., if an intervention district had a hospital, the control district also had at least one hospital;

iv. The total fertility rate (TFR) of intervention and control district pairs were similar; and

v. Proportions of women of reproductive age (WRA) were similar.

To further assess whether the selected intervention and control districts were similar, principal component analysis (PCA) was used (in this case whether they fell into the same group). The following variables were used for the PCA; the proportion of the district described as rural, number of hospitals, number of health centers and clinics, number of CHPS compounds (the lowest tier of health care provision in Ghana), TFR, and proportion of WRA. The analysis included all study districts ( 88 districts) in the four regions where the study took place: Ashanti, Central, Upper East, and Volta regions. Generally, the intervention and control districts were similar, there were slight variations across a few demographic and socioeconomic characteristics. Table 4 shows the list of the nine intervention districts with the nine selected control ones.

\subsubsection{Description of the Study Districts}

Table 1 shows the demographic and socio-economic characteristics of the intervention and control study districts. The nine districts exposed to the interventions were Bolgatanga, Nabdam, Bawku West, Obuasi, Mfantiman, Ekumfi, Upper Denkyira East, Upper Denkyira West, and Adaklu. These were matched to the following control districts respectively: Bawku Municipality, Builsa South, Builsa North, Asante Akim Central, Agona West, Agona East, Gomoa East, Assin South, and Akatsi North, which were not exposed to the intervention(s). According to the 2010 Ghana Population and Housing Census, the population of the intervention districts ranged from 33,826 (Nabdam) to 168,641 (Obuasi) while that of the control sites were from 29,777 (Akatsi North) to 207,071 (Gomoa East). Further, more than half of the districts were rural. Poverty incidence was highest in Adaklu (89.7\%) and lowest in Upper Denkyira West (3.3\%). TFR ranged between 2.4 and 4.5 births per woman across the study districts. Again, across all districts, at least seven out of 10 children ever born survived. In addition, women in their reproductive age formed at least four in 10 of the population of females in the districts ${ }^{16}$. 
TABLE 1: Matched FP Pilot intervention and control districts

\begin{tabular}{|c|c|c|c|c|c|c|c|c|}
\hline Region & $\begin{array}{l}\text { Number } \\
\text { (Match) }\end{array}$ & District & $\begin{array}{c}\text { Populati } \\
\text { on }\end{array}$ & $\begin{array}{l}\text { Poverty } \\
\text { Index }\end{array}$ & $\begin{array}{l}\text { Rur } \\
\text { al/ } \\
\text { Urb } \\
\text { an }\end{array}$ & $\begin{array}{l}T \\
F \\
R\end{array}$ & $\begin{array}{c}\% \\
\text { WR } \\
\text { A }\end{array}$ & $\begin{array}{l}\% \text { of Children } \\
\text { Surviving }\end{array}$ \\
\hline & & \multicolumn{7}{|l|}{ Intervention } \\
\hline \multirow[t]{3}{*}{$\begin{array}{l}\text { Upper } \\
\text { East }\end{array}$} & 1 & Bolgatanga & 131,550 & 27.9 & $\begin{array}{c}\text { Rura } \\
\text { I }\end{array}$ & $\begin{array}{l}3 . \\
0\end{array}$ & $\begin{array}{c}50 . \\
8\end{array}$ & 80.2 \\
\hline & 2 & Nabdam & 33,826 & 63.0 & $\begin{array}{c}\text { Rura } \\
1\end{array}$ & $\begin{array}{l}3 . \\
6\end{array}$ & $\begin{array}{c}43 . \\
4\end{array}$ & 77.9 \\
\hline & 3 & Bawku West & 94,034 & 68.1 & $\begin{array}{c}\text { Rura } \\
\text { I }\end{array}$ & $\begin{array}{l}3 . \\
7\end{array}$ & $\begin{array}{c}42 . \\
8\end{array}$ & 78.5 \\
\hline $\begin{array}{c}\text { Ashant } \\
\text { i }\end{array}$ & 4 & Obuasi & 168,641 & 5.3 & $\begin{array}{c}\text { Urba } \\
n\end{array}$ & $\begin{array}{l}2 . \\
7\end{array}$ & $\begin{array}{c}55 . \\
7\end{array}$ & 88.7 \\
\hline \multirow[t]{4}{*}{ Central } & 5 & Mfantsiman & 144,332 & 29.8 & $\begin{array}{c}\text { Urba } \\
\mathrm{n}\end{array}$ & $\begin{array}{l}3 . \\
4\end{array}$ & $\begin{array}{c}49 . \\
7\end{array}$ & 83.3 \\
\hline & 6 & Ekumfi & 52,231 & 48.4 & $\begin{array}{c}\text { Rura } \\
1\end{array}$ & $\begin{array}{l}4 . \\
0\end{array}$ & $\begin{array}{c}41 . \\
2\end{array}$ & 78.6 \\
\hline & 7 & $\begin{array}{l}\text { Upper } \\
\text { Denkyira East }\end{array}$ & 72,810 & 30.6 & $\begin{array}{c}\text { Rura } \\
\text { I }\end{array}$ & $\begin{array}{l}3 . \\
5\end{array}$ & $\begin{array}{c}50 . \\
5\end{array}$ & 84.9 \\
\hline & 8 & $\begin{array}{l}\text { Upper } \\
\text { Denkyira } \\
\text { West }\end{array}$ & 60,054 & 3.3 & $\begin{array}{c}\text { Rura } \\
1\end{array}$ & $\begin{array}{c}4 . \\
5\end{array}$ & $\begin{array}{c}46 . \\
2\end{array}$ & 85.8 \\
\hline \multirow[t]{2}{*}{ Volta } & 9 & Adaklu & 36,391 & 89.7 & $\begin{array}{c}\text { Rura } \\
\text { I }\end{array}$ & $\begin{array}{l}2 . \\
4\end{array}$ & $\begin{array}{c}50 . \\
3\end{array}$ & 89.3 \\
\hline & & \multicolumn{7}{|l|}{ Control } \\
\hline \multirow[t]{3}{*}{$\begin{array}{l}\text { Upper } \\
\text { East }\end{array}$} & 1 & $\begin{array}{l}\text { Bawku } \\
\text { Municipality }\end{array}$ & 98,538 & 42.0 & $\begin{array}{c}\text { Urba } \\
n\end{array}$ & $\begin{array}{l}2 . \\
9\end{array}$ & $\begin{array}{c}47 . \\
8\end{array}$ & 83.4 \\
\hline & 2 & Builsa South & 36,514 & 84.4 & $\begin{array}{c}\text { Rura } \\
\text { I }\end{array}$ & $\begin{array}{l}4 . \\
3\end{array}$ & $\begin{array}{c}45 . \\
8\end{array}$ & 78.9 \\
\hline & 3 & Builsa North & 56,477 & 54.3 & $\begin{array}{c}\text { Rura } \\
\text { I }\end{array}$ & $\begin{array}{l}3 . \\
6\end{array}$ & $\begin{array}{c}45 . \\
8\end{array}$ & 79.1 \\
\hline $\begin{array}{c}\text { Ashant } \\
\text { i }\end{array}$ & 4 & $\begin{array}{l}\text { Asante Akim } \\
\text { Central }\end{array}$ & 71,508 & 11.5 & $\begin{array}{c}\text { Urba } \\
n\end{array}$ & $\begin{array}{l}3 . \\
2\end{array}$ & $\begin{array}{c}42 . \\
4\end{array}$ & 88.0 \\
\hline \multirow[t]{4}{*}{ Central } & 5 & Agona West & 115,358 & 4.4 & $\begin{array}{c}\text { Urba } \\
n\end{array}$ & $\begin{array}{c}3 . \\
1\end{array}$ & $\begin{array}{c}48 . \\
3\end{array}$ & 82.7 \\
\hline & 6 & Agona East & 85,920 & 25.4 & $\begin{array}{c}\text { Rura } \\
\text { I }\end{array}$ & $\begin{array}{l}4 . \\
0\end{array}$ & $\begin{array}{c}45 . \\
4\end{array}$ & 84.1 \\
\hline & 7 & Gomoa East & 207,071 & 14.5 & $\begin{array}{c}\text { Urba } \\
n\end{array}$ & $\begin{array}{l}3 . \\
7\end{array}$ & $\begin{array}{c}53 . \\
0\end{array}$ & 85.2 \\
\hline & 8 & Assin South & 104,244 & 23.6 & $\begin{array}{c}\text { Rura } \\
\text { I }\end{array}$ & $\begin{array}{c}4 . \\
3\end{array}$ & $\begin{array}{c}44 . \\
5\end{array}$ & 84.8 \\
\hline Volta & 9 & Akatsi North & 29,777 & 26.5 & $\begin{array}{c}\text { Rura } \\
\text { I }\end{array}$ & $\begin{array}{c}4 . \\
1\end{array}$ & $\begin{array}{c}44 . \\
3\end{array}$ & 80.9 \\
\hline
\end{tabular}

Source: Ghana Statistical Service, 2012; Ghana Poverty Mapping Report, 2015 


\section{$2.4 \quad$ The FP Pilot Intervention}

In May 2018, under the leadership of the Ministry of Health (MOH), the National Health Insurance Authority (NHIA) in collaboration with Ghana Health Service (GHS), Marie Stopes International-Ghana (MSIG), and Population Council (PC) launched a pilot to include all modern clinical FP methods (e.g., injectable, implant, IUD, sterilization) into the $\mathrm{NHI}$ benefits package and expensed by facilities through the claims process. The five organizations played complementary roles in the implementation of the FP Pilot project as follows (Table 2):

TABLE 2: Roles of stakeholders in the FP Pilot Project

\begin{tabular}{|c|c|}
\hline Organization & Role \\
\hline Ministry of Health & To oversee the implementation of the pilot project \\
\hline $\begin{array}{l}\text { National Health Insurance } \\
\text { Authority }\end{array}$ & $\begin{array}{l}\text { To lead the management of the implementation of } \\
\text { the pilot project }\end{array}$ \\
\hline Ghana Health Service & $\begin{array}{l}\text { To coordinate the implementation of the pilot } \\
\text { project in health facilities and provider training on } \\
\text { LARCs service provision }\end{array}$ \\
\hline $\begin{array}{l}\text { Marie Stopes International } \\
\text { Ghana }\end{array}$ & $\begin{array}{l}\text { To provide financial support and coordinating the } \\
\text { activities of the project }\end{array}$ \\
\hline Population Council & To undertake the evaluation of the intervention \\
\hline
\end{tabular}

The FP Pilot interventions were implemented in 158 public and private NHIA-credentialled facilities across the nine intervention districts. Three different interventions were implemented-OP cost removal for FP services, demand generation, and provider training on long-acting reversible contraceptive (LARC) service delivery (Table 3). Five different combinations of the three interventions were implemented in the nine districts:

i. OP cost removal for FP services + demand generation + LARCs training in one district;

ii. OP cost removal for FP services + LARCs training in one district;

iii. OP cost removal for FP services only in five districts;

iv. Demand generation only in one district; and

v. LARCs training only in one district.

In summary, the OP cost removal for FP services package was implemented in seven districts, two districts had FP demand generation intervention, and in three districts, selected providers were trained on LARCs insertion and removal. The pilot interventions started in May 2018 and ended in July 2020. 
TABLE 3: Interventions implemented in the nine FP Pilot intervention districts

\begin{tabular}{|c|c|c|c|c|c|c|c|c|c|}
\hline \multirow[b]{2}{*}{$\begin{array}{l}\text { Intervent } \\
\text { ion }\end{array}$} & \multicolumn{9}{|c|}{ FP Pilot Districts } \\
\hline & $\begin{array}{c}\text { Bolgatan } \\
\text { ga }\end{array}$ & $\begin{array}{l}\text { Nabd } \\
\text { am }\end{array}$ & $\begin{array}{c}\text { Baw } \\
\text { ku } \\
\text { West }\end{array}$ & $\begin{array}{l}\text { Obu } \\
\text { asi }\end{array}$ & $\begin{array}{l}\text { Mfantsim } \\
\text { an }\end{array}$ & $\begin{array}{l}\text { Eku } \\
\text { mfi }\end{array}$ & $\begin{array}{c}\text { Adak } \\
\text { lu }\end{array}$ & $\begin{array}{c}\text { Upper } \\
\text { Denky } \\
\text { ira } \\
\text { East }\end{array}$ & $\begin{array}{c}\text { Upper } \\
\text { Denkyir } \\
\text { a West }\end{array}$ \\
\hline $\begin{array}{l}\text { OP cost } \\
\text { removal } \\
\text { for } \\
\text { FP } \\
\text { services }\end{array}$ & & & & & & & & & \\
\hline $\begin{array}{l}\text { LARCS } \\
\text { training }\end{array}$ & & & & & & & & & \\
\hline $\begin{array}{l}\text { Demand } \\
\text { generati } \\
\text { on }\end{array}$ & & & & & & & & & \\
\hline Facilities & 30 & 14 & 27 & 14 & 12 & 12 & 13 & 25 & 11 \\
\hline
\end{tabular}

Note: The FP Pilot intervention considered facilities that provide FP services and are credentialled by NHIA; Upper Denkyira East and Upper Denkyira West were not included in the analysis for the evaluation.

\subsubsection{Description of the Interventions}

\section{Intervention 1: Removal of out-of-pocket costs of FP services}

This was the primary intervention of the FP Pilot. It was implemented in seven districts (Bolgatanga, Nabdam, Bawku West, Mfantsiman, Ekumfi, Obuasi, and Adaklu). In Ghana, FP services are provided in both public and private healthcare facilities. Because, in practice, FP is not fully covered under the NHIS benefit package, clients pay out-of-pocket for FP services. The government of Ghana and its development partners procure FP commodities (e.g., implants, IUDs, injectables, etc.) and through the Ghana Health Service distribution channels, these commodities are distributed to public and private facilities. Hence, the OP fee paid by clients does not include the cost of commodities but are fees meant to cover the cost of consumables for providing the service, transportation, distribution, and storage of commodities. The FP Pilot, therefore sought to remove OP payment by asking credentialled public and private healthcare providers to provide clinical FP methods (vasectomy, bilateral tubal ligation, implants, IUDs, and injectables) to NHIS insured clients and complete the claims forms for submission and reimbursement.

Intervention 2: LARCs training in selected facilities in pilot and control districts

This was an additional intervention implemented in three districts (Bolgatanga, Adaklu, and Upper Denkyira East) where some providers received LARCs training. The three districts were selected for two reasons. The first was that two of these districts (Bolgatanga and Upper Denkyira East) were among the districts identified at the start of the pilot with a significant lack of FP providers trained in LARCs service provision. The second reason was to get a rural perspective of the effect of LARCs training on FP uptake, hence, the inclusion of Adaklu district-a predominantly rural district. The LARCs intervention trained selected community health nurses (CHNs) and midwives lacking formal training in LARCs service provision. The selection of participants was based on a LARCs needs assessment 
in the provider baseline survey that identified skills gaps for implant and IUD insertion and removal. Due to resource and time constraints, the LARCs training intervention could not include all CHNs and midwives lacking implant and IUD insertion and removal in the 3 districts. Instead, the training selected some of the untrained staff per district so that, most, if not all health centers and the district hospitals had at least one FP service provider trained and capable of providing LARCs. Table 4 presents the distribution of midwives and CHNs by district.

TABLE 4: Number of CHNs and Midwives Training Needs Gap

\begin{tabular}{|c|c|c|c|c|c|c|c|c|}
\hline \multirow[t]{2}{*}{ District } & \multicolumn{4}{|c|}{ Midwives } & \multicolumn{4}{|l|}{ CHNs } \\
\hline & $\begin{array}{l}\text { Total } \\
\text { numb } \\
\text { er }\end{array}$ & $\begin{array}{l}\text { Numb } \\
\text { er } \\
\text { traine } \\
d \text { in } \\
\text { LARCs }\end{array}$ & $\begin{array}{l}\text { Number } \\
\text { untrain } \\
\text { ed in } \\
\text { LARCs }\end{array}$ & $\begin{array}{l}\text { Numb } \\
\text { er } \\
\text { traine } \\
d \text { in } \\
\text { LARCs } \\
\text { for the } \\
\text { pilot }\end{array}$ & $\begin{array}{l}\text { Total } \\
\text { numb } \\
\text { er }\end{array}$ & $\begin{array}{l}\text { Numb } \\
\text { er } \\
\text { traine } \\
d \text { in } \\
\text { LARCs }\end{array}$ & $\begin{array}{l}\text { No. } \\
\text { untrain } \\
\text { ed in } \\
\text { LARCs }\end{array}$ & $\begin{array}{l}\text { Numb } \\
\text { er } \\
\text { traine } \\
d \text { in } \\
\text { LARCs } \\
\text { for the } \\
\text { pilot }\end{array}$ \\
\hline $\begin{array}{l}\text { Bolgatan } \\
\text { ga }\end{array}$ & 80 & 52 & 28 & 10 & 140 & 67 & 73 & 15 \\
\hline Adaklu & 13 & 3 & 10 & 10 & 40 & 5 & 35 & 15 \\
\hline $\begin{array}{l}\text { Upper } \\
\text { Denkyira } \\
\text { East }\end{array}$ & 12 & 1 & 11 & 10 & 62 & 38 & 24 & 15 \\
\hline Total & & & & 30 & & & & 45 \\
\hline
\end{tabular}

\section{Intervention 3: Demand generation for FP}

The third intervention, demand generation, was implemented in two districts (Bolgatanga and Upper Denkyira West). These districts were selected based on the generally low state of awareness on FP issues (e.g. unaware of FP importance in family wellbeing, high prevalence of myths and misconceptions) identified at the start of the project. The demand generation component of this intervention included education activities to address FP myths and misconceptions through mass media and other campaigns.

\subsection{Source of Data}

Facility service data on uptake of FP and method mix were extracted from the District Health Information Management System (DHIMS) database from January 2017 to February 2020 for all the intervention and control districts (data was extracted on the $5^{\text {th }}$ February 2021). DHIMS is a nationwide health information data capture system that is used to capture service data including FP.

\subsection{Statistical Analysis for Evaluation}

To assess the impact of the FP Pilot on FP service utilization, this study used two outcome indicators 1) number of new FP acceptors, and 2) number of new FP acceptors by methods (IUDs, implants, injectables, and oral contraceptives). As earlier indicated, the FP Pilot considered clinical FP methods (e.g., injectable, implant, IUD, and sterilization). Hence, 
oral contraceptives were not included in the pilot intervention. However, it is anticipated that the FP Pilot intervention activities such as awareness creation (implemented in all intervention districts), demand generation (in selected districts), and provider training (in selected districts) could have influenced the uptake of other FP methods such as oral contraceptives. The overall study period was from January 2017 to February 2020 split into two phases: pre-intervention (January 2017 to April 2018), and intervention (May 2018 to February 2020). The evaluation data was limited to February 2020 because of the onset of COVID-19 in March 2020 and its expected impact on FP service uptake. In this report, we focus on the new FP acceptors indicator as it is an indicator that signifies the potential of an intervention to draw new clients as well as increase in uptake of FP17.

The interrupted time series (ITS) approach was used to assess the impact of the interventions. The controlled ITS (multiple-group analyses) was utilized. The use of the control ITS requires similar comparison groups which are not exposed to the intervention to analyze a before-after comparison and an intervention-control comparison. The benefit of this design is that it helps control for history bias due to time-varying confounders, in particular co-interventions and other events concurrent with the intervention. Series of controlled ITS segmented ordinary least square regression models were estimated, one for each of the two indicators across the different combinations of the interventions using the onset month of the FP Pilot interventions (May 2018) as the event. The analyses were done using the Prais-Winsten method ${ }^{18}$. The analyses also took into consideration the potential effect of seasonality in FP service utilization on the outcome variables. The controlled ITS regression model takes the form:

$$
Y_{t}=\beta_{0}+\beta_{1} T_{t}+\beta_{2} X_{t}+\beta_{3} X_{t} T_{t}+\beta_{4} Z+\beta_{5} Z T_{t}+\beta_{6} Z X_{t}+\beta_{7} Z X_{t} T_{t}+\varepsilon_{t}
$$

Where $Y_{t}$ is the aggregated outcome variable measured at each equally spaced time point $t$. $\beta_{0}$ represents the intercept or starting level of the outcome variable (estimated number of FP acceptors at the beginning of the pre-outbreak period). $\beta_{1}$ estimates the average monthly change in the number of FP acceptors until the introduction of the intervention (COVID-19). $T_{t}$ is the time since the start of the study, $\beta_{2}$ represents the change in the level of service use that occurred in the period immediately following the introduction of the intervention (compared with the counterfactual), $\beta_{3}$ represents the difference between the trend in FP service use pre-COVID-19 (preintervention) and during COVID-19 (during intervention) periods. $X_{t}$ is a dummy (indicator) variable representing the intervention (preintervention periods 0 , otherwise 1 ), $X_{t} T_{t}$ is an interaction term and $\epsilon_{t}$ the random error term.

Further, $Z$ is a dummy variable denoting the cohort assignment (treatment or control), and $Z T_{t}, Z X_{t}$, and $Z X_{t} T_{t}$ are all interaction terms among previously described variables. $\beta_{4}$ represents the difference in the level (intercept) of the outcome variable between treatment and controls prior to the intervention, $\beta_{5}$ represents the difference in the slope (trend) of the outcome variable between treatment and controls prior to the intervention, $\beta_{6}$ indicates the difference between treatment and control groups in the level of the outcome variable immediately following the introduction of the intervention, and $\beta_{7}$ represents the difference between treatment and control groups in the slope (trend) of the

\footnotetext{
17 Bertrand, J., Magnani, R. J., \& Rutenberg, N. (1994). Handbook of Indicators for Family Planning Program Evaluation. http://www.cpc.unc.edu/measure/publications/ms-94-01

18 Linden, A. (2015). Conducting interrupted time-series analysis for single- and multiple-group comparisons. Stata Journal, 15(2), 480-500.
} 
outcome variable after initiation of the intervention compared with pre-intervention. The data was analyzed using Stata version 16.

\subsection{Ethical consideration}

Ethical approval was obtained from the Ghana Health Service Ethics Review Committee and the Population Council Institutional Review Board. Permission was sought from the Family Health Division of Ghana Health Service to use the DHIMs data.

\subsection{Limitations}

Conscious efforts were made to select the most appropriate comparison districts in the design phase of the study, but it is possible that the selected comparison districts did not serve as the most appropriate counterfactuals as other programs or policy changes may have influenced the indicators of interest in the intervention or comparison districts differently. This limitation notwithstanding, the statistical analyses are appropriate and robust and allow for interpretation of the results to inform policy decision-making. 
The analyses were conducted in line with the combination of interventions that were implemented to assess the impact of the interventions on uptake of FP and method mix. The combination of interventions considered in this analysis are (also see Table 3):

i. OP cost removal for FP services + other interventions (all seven intervention districts with OP cost removal);

ii. OP cost removal for FP services only (five intervention districts);

iii. OP cost removal for FP services + demand generation + LARCs training (one intervention district); and

iv. OP cost removal for FP services + LARCs training (one intervention district).

Subsequent sections will assess each of the four different sets of interventions and their impact on the number of new FP acceptors and method-specific new FP acceptors. For each section, the analyses are presented in four parts:

i. Impact of the intervention(s) on new FP acceptors (total);

ii. Impact of the intervention(s) on new IUD acceptors;

iii. Impact of the intervention(s) on new implant acceptors;

iv. Impact of the intervention(s) on new injectable acceptors; and

v. Impact (unintended) of the intervention(s) on new oral contraceptive acceptors.

As it is done in standard reporting of multiple groups ITS, for each FP indicator we present the intervention and control group comparison together and report on whether or not there was:

- Any significant difference in the level of the outcome between treatment and control districts at baseline;

- Any significant difference in the slope between intervention and control districts prior to the intervention;

- A significant difference in the level between intervention and control in the period immediately following intervention initiation;

- Any significant difference between intervention and control in the slope after initiation of the intervention compared with pre-intervention period; and

- Long-term effect. 
3.1 Impact of Out-of-Pocket Cost Removal for FP Services and Any Other Intervention on Uptake of FP and Method Mix (All Seven Intervention Districts with OP Cost Removal)

This section examines the impact of OP cost removal for FP services and other interventions on new FP acceptors as well as IUD, implant, injectable, and oral contraceptive acceptors. This involves all seven intervention districts with OP cost removal for FP services compared with seven corresponding control districts.
FIGURE 2: Trends in new FP acceptors (January 2017 February 2020)

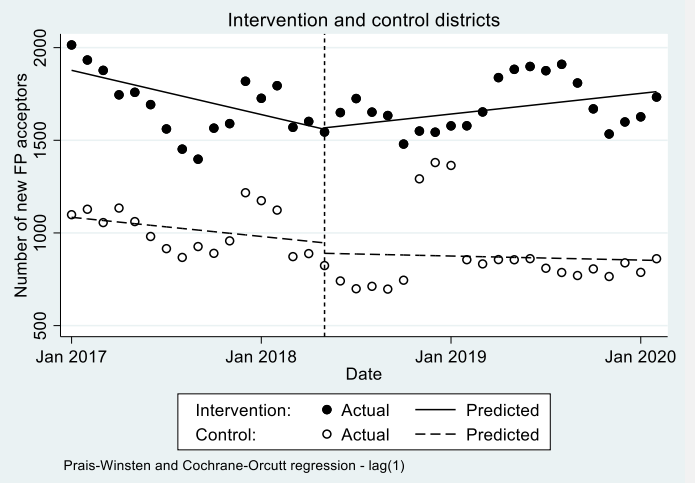

\subsubsection{Impact on New FP Acceptors}

Table 5 shows findings of the impact of OP cost removal for FP services and any other intervention on the number of new FP acceptors (intervention and control districts).

As shown in Table 5 and Figure 2, before the intervention, the number of new FP acceptors in both the intervention and control districts was on the decline but declining at a higher rate in the intervention districts (Coef. = -11.3; not significant). In the first month of the intervention (May 2018) however, there was a positive effect on the number of new FP acceptors in the intervention districts (Coef. $=64.4$; not significant). The number of new FP acceptors trended towards an increase in the intervention districts pre- and during the intervention trend compared with that of control districts (Coef. $=22.4$; not significant). During the intervention period, the number of new FP acceptors in the intervention districts increased at a rate of 9.3 (C.I. $=-3.5,22.1)$ women per month compared with the control districts, which continued to trend downward (Coef. $=-1.8$ ) but both were not statistically significant. Although the intervention (OP cost removal for FP services and other interventions) did not appear to have a statistically significant effect on uptake of contraception, it did show improvement in the intervention districts given that prior to the intervention, the trend in the number of new FP acceptors was on the downward trend and improved drastically during the intervention period. 
TABLE 5: ITS parameter estimates for monthly new FP acceptors - seven intervention and control districts

\begin{tabular}{|c|c|c|}
\hline Variable & $\begin{array}{l}\text { New FP } \\
\text { acceptors }\end{array}$ & 95\% C. I. \\
\hline $\begin{array}{l}\text { Number of new FP acceptors (in control group) in } \\
\text { Jan. } 2017\left(\beta_{0}\right)\end{array}$ & $1084.6 * * *$ & $989.2,1179.9$ \\
\hline $\begin{array}{l}\text { Average monthly change in number of new FP } \\
\text { acceptors (in control group), Jan. 2017-Apr. } 2018 \\
\left(\beta_{1}\right)\end{array}$ & -8.6 & $-29.6,12.3$ \\
\hline $\begin{array}{l}\text { Change in level of FP acceptors (in control group) } \\
\text { in May } 2018\left(\beta_{2}\right)\end{array}$ & -56.4 & $-225.8,113.0$ \\
\hline $\begin{array}{l}\text { Change in trend in monthly number of FP } \\
\text { acceptors (in control group) between Jan. } 2017- \\
\text { Apr. } 2018 \text { compared to May 2018-Feb. } 2020\left(\beta_{3}\right)\end{array}$ & 6.8 & $-23.3,36.9$ \\
\hline $\begin{array}{l}\text { Difference in number of new FP acceptors } \\
\text { between intervention and control groups in Jan. } \\
2017\left(\beta_{4}\right)\end{array}$ & $793.2 * * *$ & $556.2,1030.2$ \\
\hline $\begin{array}{l}\text { Difference in trend in monthly number of new FP } \\
\text { acceptors between intervention and control } \\
\text { groups from Jan } 2017-A p r .2020\left(\beta_{5}\right)\end{array}$ & -11.3 & $-43.0,20.5$ \\
\hline $\begin{array}{l}\text { Difference in the change in level of new FP } \\
\text { acceptors between intervention and control } \\
\text { groups in May } 2018\left(\beta_{6}\right)\end{array}$ & 64.4 & $-169.5,298.4$ \\
\hline $\begin{array}{l}\text { Difference in change in trend in monthly number } \\
\text { of new FP acceptors between treatment and } \\
\text { control from Jan. } 2017-A \text { pr. } 2018 \text { compared to } \\
\text { May 2018-Feb. } 2020\left(\beta_{7}\right)\end{array}$ & 22.4 & $-21.8,66.6$ \\
\hline $\begin{array}{l}\text { Average monthly change in number of new FP } \\
\text { acceptors from May 2018-Feb. } 2020 \text { (in } \\
\text { intervention group) }\end{array}$ & 9.3 & $-3.5,22.1$ \\
\hline $\begin{array}{l}\text { Average monthly change in number of new FP } \\
\text { acceptors from May } 2018-F e b .2020 \text { (in control } \\
\text { group) }\end{array}$ & -1.8 & $-12.8,9.1$ \\
\hline Difference & 11.1 & $-5.7,28.0$ \\
\hline rho & 0.670 & \\
\hline Durbin-Watson statistic (original) & 0.668 & \\
\hline Durbin-Watson statistic (transformed) & 1.576 & \\
\hline
\end{tabular}

Note: ${ }^{+} p<.1 ; * p<.05 ; * * p<.01 ; * * * p<.001$; Source: Ghana DHIMS data, January 2017 to February 2020 


\subsubsection{Impact on New IUD and Implant Acceptors}

Table 6 presents results of the impact of OP cost removal for FP services and other interventions on new IUD and implant acceptors (intervention and control districts).

\section{New IUD Acceptors}

Model M1 on Table 6 and Figure 3 show that comparing the intervention and control districts, at baseline the difference in the number of new IUD acceptors was significant (Coef. $=19.3 ;$ C.I. $=14.6,24.1)$ with the intervention districts being higher than the control districts. The difference in trend in new IUD acceptors between intervention and control districts prior to the start of the intervention was statistically significantly different (Coef. $=-0.8$; C.I. $=-2.0,16.3$ ), showing that whereas the number of new IUD acceptors in the intervention districts was trending downward, it was trending upward in the control districts. Additionally, there was no statistically significant intervention effect during the first month of the intervention. However, there was a positive statistically significant monthly increase in the pre- and during the intervention trend in the intervention districts compared with that of the controls of 1.9 new IUD acceptors $(C . I .=1.1,2.7)$. Further, there was evidence that during the intervention, the number of new IUD acceptors in the intervention districts increased significantly at a rate of 0.9 new IUD acceptors per month. But, in the control districts, new IUD acceptors per month was decreasing significantly at a rate of 0.2 new IUD acceptors per month over the same period. The difference between the intervention and control districts was 1.1 new IUD acceptors per month. The results show that the intervention had a significant effect on the number of new IUD acceptors. Although there was no immediate effect in the first month of the intervention (OP cost removal for FP services and any other intervention), there appeared to be a significant long-term positive impact on the number of new IUD acceptors.

\section{New Implant Acceptors}

Model M2 on Table 6 and visualized in Figure 4, show no statistically significant difference in new implants acceptors between the intervention and control districts at baseline, in the first month of the intervention, and during the intervention period. However, while the trend in the intervention districts was gradually increasing during the intervention period at a rate of 1.8 new implants acceptors (not significant) per month, in the control districts, it was increasing at a rate of 1.2 new implant acceptors (not significant) per month. Even though the intervention (OP cost removal for FP services and any other intervention) did not have a significant effect on the uptake of implant acceptors, there appears to be some marginal improvement during the intervention period.
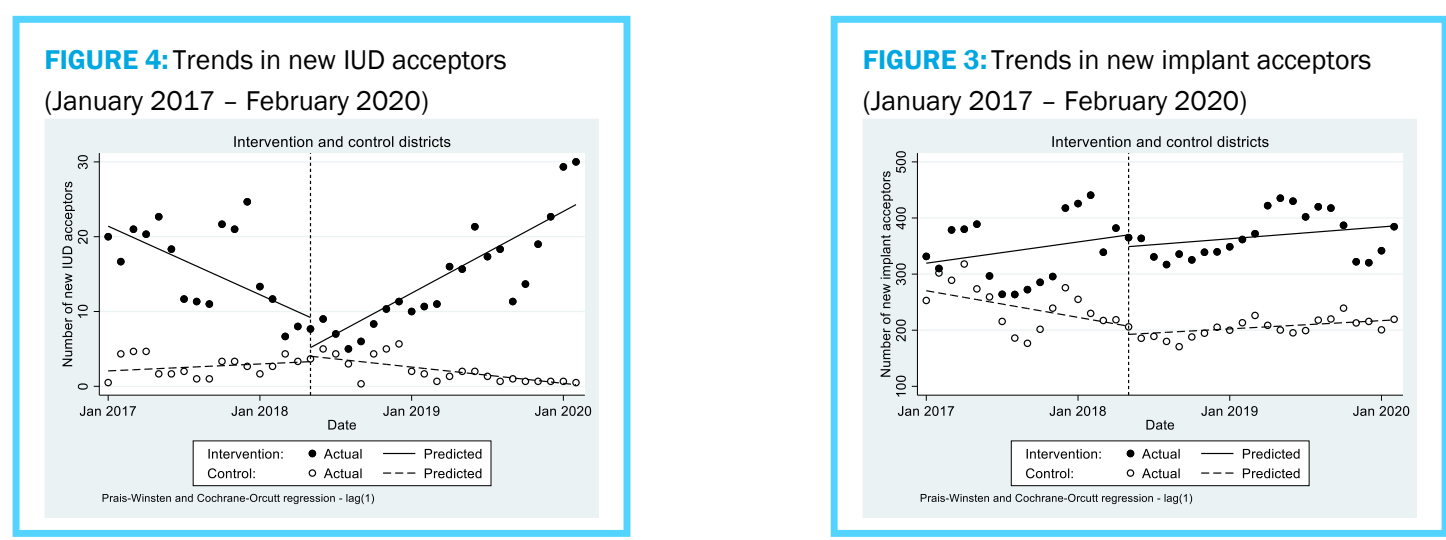
TABLE 6: ITS parameter estimates for monthly new FP acceptors - seven intervention and control districts

\begin{tabular}{|c|c|c|c|c|}
\hline \multirow[b]{2}{*}{ Variable } & \multicolumn{2}{|c|}{ IUDs (M1) } & \multicolumn{2}{|c|}{ Implants (M2) } \\
\hline & Coef. & 95\% C. I. & Coef. & 95\% C. I. \\
\hline $\begin{array}{l}\text { Number of new FP acceptors (in } \\
\left.\text { control group) in Jan. } 2017 \text { ( } \beta_{0}\right)\end{array}$ & 2.1 & $-0.6,4.8$ & $270.4 * * *$ & $223.7,317.0$ \\
\hline $\begin{array}{l}\text { Average monthly change in number } \\
\text { of new FP acceptors (in control } \\
\text { group), Jan. 2017-Apr. } 2018\left(\beta_{1}\right)\end{array}$ & 0.1 & $-0.2,0.3$ & $-4.0 *$ & $-7.9,0.0$ \\
\hline $\begin{array}{l}\text { Change in level of FP acceptors (in } \\
\text { control group) in May } 2018\left(\beta_{2}\right)\end{array}$ & 0.7 & $-1.2,2.6$ & -14.5 & $-43.6,14.5$ \\
\hline $\begin{array}{l}\text { Change in trend in monthly number } \\
\text { of FP acceptors (in control group) } \\
\text { between Jan. 2017-Apr. } 2018 \\
\text { compared to May 2018-Feb. } 2020 \\
\left(\beta_{3}\right)\end{array}$ & $-0.3+$ & $-0.5,0.0$ & $5.2^{*}$ & $0.1,10.2$ \\
\hline $\begin{array}{l}\text { Difference in number of new FP } \\
\text { acceptors between intervention and } \\
\text { control groups in Jan. } 2017\left(\beta_{4}\right)\end{array}$ & $19.3 * * *$ & $14.6,24.1$ & 49.0 & $-25.7,123.7$ \\
\hline $\begin{array}{l}\text { Difference in trend in monthly } \\
\text { number of new FP acceptors } \\
\text { between intervention and control } \\
\text { groups from Jan } 2017-A p r .2020 \\
\left(\beta_{5}\right)\end{array}$ & $-0.8 * *$ & $-1.4,-0.2$ & 7.1 & $-2.0,16.3$ \\
\hline $\begin{array}{l}\text { Difference in the change in level of } \\
\text { new FP acceptors between } \\
\text { intervention and control groups in } \\
\text { May } 2018\left(\beta_{6}\right)\end{array}$ & -4.7 & $-12.3,2.8$ & -6.4 & $-77.4,64.5$ \\
\hline $\begin{array}{l}\text { Difference in change in trend in } \\
\text { monthly number of new FP } \\
\text { acceptors between treatment and } \\
\text { control from Jan. 2017-Apr. } 2018 \\
\text { compared to May 2018-Feb. } 2020 \\
\left(\beta_{7}\right)\end{array}$ & $1.9 * * *$ & 1.1,2.7 & -6.6 & $-19.0,5.9$ \\
\hline $\begin{array}{l}\text { Average monthly change in number } \\
\text { of new FP acceptors from May } \\
2018 \text {-Feb. } 2020 \text { (in intervention } \\
\text { group) }\end{array}$ & $0.9 * * *$ & $0.5,1.3$ & 1.8 & $-2.5,6.1$ \\
\hline $\begin{array}{l}\text { Average monthly change in number } \\
\text { of new FP acceptors from May } \\
\text { 2018-Feb. } 2020 \text { (in control group) }\end{array}$ & $-0.2 * * *$ & $-0.3,-0.1$ & 1.2 & $-0.8,3.2$ \\
\hline Difference & $1.1 * * *$ & $0.7,1.5$ & 0.5 & $-4.2,5.3$ \\
\hline rho & 0.478 & & 0.640 & \\
\hline Durbin-Watson statistic (original) & 1.068 & & 0.722 & \\
\hline $\begin{array}{l}\text { Durbin-Watson statistic } \\
\text { (transformed) }\end{array}$ & 1.682 & & 1.653 & \\
\hline
\end{tabular}

Note: ${ }^{+} \mathrm{p}<.1 ; * \mathrm{p}<.05 ; * * \mathrm{p}<.01 ; * * * \mathrm{p}<.001$; Source: Ghana DHIMS data, January 2017 to February 2020 


\subsubsection{Impact on New Injectable and Oral Contraceptive Acceptors}

Table 7 presents findings of the impact of OP cost removal for FP services and other interventions on new injectable and oral contraceptive acceptors (intervention and control districts).

\section{New Injectable Acceptors}

Comparing intervention and control districts (Model M1 on Table 7), there was no statistically significant difference in the trend in the number of new injectable acceptors pre-intervention. However, from Figure 5, it is noticed that preintervention, new injectable acceptors in the intervention and control districts showed a downward trend, with the intervention districts decreasing at a higher rate (Coef. = -9.9; not significant).

Whereas there was no statistically significant

FIGURE 5: Trends in new injectable acceptors (January 2017 - February 2020)

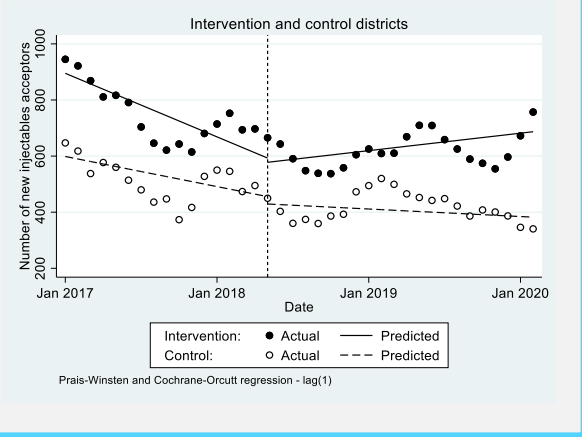
intervention effect during the first month of the intervention, there was a marginal positive statistically significant monthly increase in the pre- and during intervention trend in the intervention districts compared with that of the controls of 17.4 new injectable acceptors $($ C.I. $=-5.9,40.7)$. From the results, during the intervention period, the number of new injectable acceptors in the intervention districts were increasing monthly at a rate of 5.2 new users per month and in the control districts, decreasing at a rate of 2.2 new users per month (not significant) (Model M1 on Table 7 and Figure 5). From the results, the findings showed a marginal improvement in the number of new injectable acceptors as there was an improvement in the intervention districts during the intervention period.

\section{New Oral Contraceptive Acceptors}

From Model M2 on Table 7, the difference in the slope between the intervention and control districts pre-intervention was not statistically significant (Coef. $=-3.3$ ). However, from Figure 6, it is found that pre-intervention, the trend in the number of new oral contraceptive acceptors was decreasing in the intervention districts and increasing in the control districts. Additionally, there was no statistical evidence of the intervention effect in the first month of the intervention. Unlike pre-intervention, it is observed that during the intervention period, new

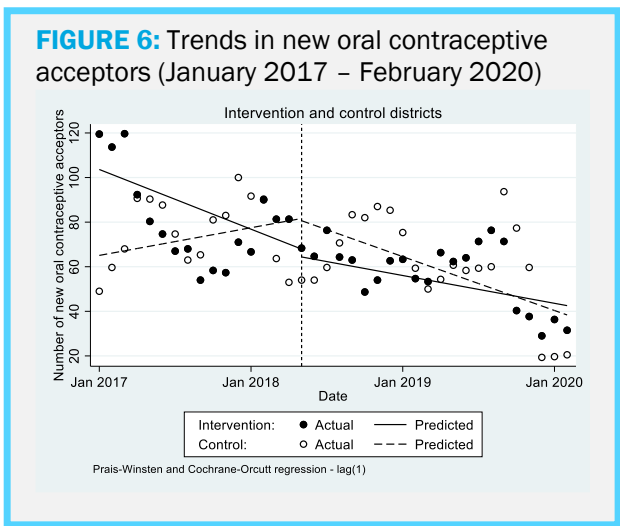
oral contraceptive acceptors in both the intervention and control districts were on the decline (not significant) but decreasing at a higher rate in the intervention districts compared to the control districts (Figure 6). The findings did not show evidence of the intervention having an unintended improvement in the uptake of oral contraception. 
TABLE 7: ITS parameter estimates for monthly new FP acceptors - seven intervention and control districts

\begin{tabular}{|c|c|c|c|c|}
\hline \multirow[b]{2}{*}{ Variable } & \multicolumn{2}{|c|}{ Injectables (M1) } & \multicolumn{2}{|c|}{$\begin{array}{l}\text { Oral contraceptives } \\
\text { (M2) }\end{array}$} \\
\hline & Coef. & 95\% C. I. & Coef. & 95\% C. I. \\
\hline $\begin{array}{l}\text { Number of new FP acceptors (in control } \\
\text { group) in Jan. } 2017\left(\beta_{0}\right)\end{array}$ & $\begin{array}{c}598.6 * * \\
*\end{array}$ & $\begin{array}{c}502.3,694 \\
8\end{array}$ & $\begin{array}{c}65.1 * * \\
*\end{array}$ & $36.2,93.9$ \\
\hline $\begin{array}{l}\text { Average monthly change in number of } \\
\text { new FP acceptors (in control group), Jan. } \\
\text { 2017-Apr. } 2018\left(\beta_{1}\right)\end{array}$ & -8.9 & $-20.0,2.2$ & 1.0 & $-2.2,4.3$ \\
\hline $\begin{array}{l}\text { Change in level of FP acceptors (in control } \\
\text { group) in May } 2018\left(\beta_{2}\right)\end{array}$ & -26.3 & $-79.0,26.4$ & -1.0 & $-23 \cdot 0,21 \cdot 0$ \\
\hline $\begin{array}{l}\text { Change in trend in monthly number of FP } \\
\text { acceptors (in control group) between Jan. } \\
\text { 2017-Apr. } 2018 \text { compared to May 2018- } \\
\text { Feb. } 2020\left(\beta_{3}\right)\end{array}$ & 6.7 & $-9.1,22.5$ & -3.0 & $-7.9,1.8$ \\
\hline $\begin{array}{l}\text { Difference in number of new FP acceptors } \\
\text { between intervention and control groups } \\
\text { in Jan. } 2017\left(\beta_{4}\right)\end{array}$ & $\begin{array}{c}296.4 * * \\
*\end{array}$ & $\begin{array}{c}162.2,430 \\
7\end{array}$ & $38.5+$ & $-1.7,78.8$ \\
\hline $\begin{array}{l}\text { Difference in trend in monthly number of } \\
\text { new FP acceptors between intervention } \\
\text { and control groups from Jan 2017-Apr. } \\
2020 \text { ( } \beta 5 \text { ) }\end{array}$ & -9.9 & $-25.5,5.6$ & -3.3 & $-7.5,1.0$ \\
\hline $\begin{array}{l}\text { Difference in the change in level of new } \\
\text { FP acceptors between intervention and } \\
\text { control groups in May } 2018\left(\beta_{6}\right)\end{array}$ & 11.2 & $-72.9,95.3$ & -2.5 & $-29.2,24.1$ \\
\hline $\begin{array}{l}\text { Difference in change in trend in monthly } \\
\text { number of new FP acceptors between } \\
\text { treatment and control from Jan. 2017- } \\
\text { Apr. } 2018 \text { compared to May 2018-Feb. } \\
2020\left(\beta_{7}\right)\end{array}$ & $17.4+$ & $-5.9,40.7$ & 4.2 & $-1.8,10.3$ \\
\hline $\begin{array}{l}\text { Average monthly change in number of } \\
\text { new FP acceptors from May 2018-Feb. } \\
2020 \text { (in intervention group) }\end{array}$ & 5.2 & $-3.6,13.9$ & -1.0 & $-2.6,0.5$ \\
\hline $\begin{array}{l}\text { Average monthly change in number of } \\
\text { new FP acceptors from May 2018-Feb. } \\
2020 \text { (in control group) }\end{array}$ & -2.2 & $-8.1,3.6$ & -2.0 & $-4.5,0.5$ \\
\hline Difference & 7.4 & $-3.1,17.9$ & 1.0 & $-1.9,3.9$ \\
\hline rho & 0.768 & & 0.703 & \\
\hline Durbin-Watson statistic (original) & 0.460 & & 0.613 & \\
\hline Durbin-Watson statistic (transformed) & 1.235 & & 1.542 & \\
\hline
\end{tabular}

Note: ${ }^{+} p<.1 ; * p<.05 ; * * p<.01 ; * * * p<.001$; Source: Ghana DHIMS data, January 2017 to February 2020 


\subsection{Impact of Out-of-Pocket Cost Removal for FP Services Only on Uptake of FP and Method Mix (Five Intervention Districts)}

This section examines the impact of OP cost removal for FP services on new FP acceptors, and also on IUD, Implant, Injectable, and oral contraceptive acceptors. This involves the five intervention districts where OP cost removal for FP services only was implemented compared with the five corresponding control districts.

\subsubsection{Impact on New FP Acceptors}

Table 8 presents results of the impact of OP cost removal for FP services only on new FP acceptors (intervention and control districts).

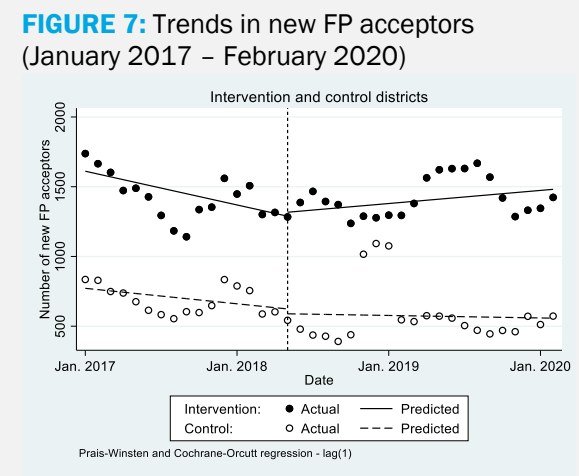

Comparing the intervention and control districts

(Table 8), new FP acceptors were significantly higher in the intervention districts compared to the control districts at baseline (Coef. $=839.6$; C.I. $=604.9,1074.3$ ), however, the trend over the pre-intervention period between the intervention and control districts was not significantly different. The impact of the intervention in the first month appeared to be positive, although not significant (Coef. 63.0; C.I. -145.1, 271.1). Worth noting however is that unlike the pre-intervention downward trend in both intervention and control districts, during the intervention period, new FP acceptors appeared to be increasing at a rate of 7.8 new FP acceptors in the intervention districts and continued on a declining trend in the control districts at a rate of 1.5 new FP acceptors (not significant) (also Figure 7 ). The impact of OP cost removal for FP services only appeared to have had a positive impact on uptake of FP services as it showed noticeable improvement during the intervention period (although not statistically significant). 
TABLE 8: ITS parameter estimates for monthly new FP acceptors - five intervention and control districts

\begin{tabular}{|c|c|c|}
\hline Variable & New FP acceptors & 95\% C. I. \\
\hline $\begin{array}{l}\text { Number of new FP acceptors (in control } \\
\text { group) in Jan. } 2017\left(\beta_{0}\right)\end{array}$ & $771.6 * * *$ & $656.1,887.0$ \\
\hline $\begin{array}{l}\text { Average monthly change in number of new } \\
\text { FP acceptors (in control group), Jan. 2017- } \\
\text { Apr. } 2018\left(\beta_{1}\right)\end{array}$ & -9.2 & $-27.1,8.6$ \\
\hline $\begin{array}{l}\text { Change in level of FP acceptors (in control } \\
\text { group) in May } 2018\left(\beta_{2}\right)\end{array}$ & -34.7 & $-174.5,105.2$ \\
\hline $\begin{array}{l}\text { Change in trend in monthly number of FP } \\
\text { acceptors (in control group) between Jan. } \\
2017-A p r .2018 \text { compared to May 2018- } \\
\text { Feb. } 2020\left(\beta_{3}\right)\end{array}$ & 7.7 & $-17.8,33.3$ \\
\hline $\begin{array}{l}\text { Difference in number of new FP acceptors } \\
\text { between intervention and control groups in } \\
\text { Jan. } 2017\left(\beta_{4}\right)\end{array}$ & $839.6 * * *$ & $604.9,1074.3$ \\
\hline $\begin{array}{l}\text { Difference in trend in monthly number of } \\
\text { new FP acceptors between intervention and } \\
\text { control groups from Jan 2017-Apr. } 2020\left(\beta_{5}\right)\end{array}$ & -10.9 & $-39.6,17.8$ \\
\hline $\begin{array}{l}\text { Difference in the change in level of new FP } \\
\text { acceptors between intervention and control } \\
\text { groups in May } 2018\left(\beta_{6}\right)\end{array}$ & 63.0 & $-145.1,271.1$ \\
\hline $\begin{array}{l}\text { Difference in change in trend in monthly } \\
\text { number of new FP acceptors between } \\
\text { treatment and control from Jan. 2017-Apr. } \\
2018 \text { compared to May 2018-Feb. } 2020 \\
\left(\beta_{7}\right)\end{array}$ & 20.2 & $-19.7,60.1$ \\
\hline $\begin{array}{l}\text { Average monthly change in number of new } \\
\text { FP acceptors from May 2018-Feb. } 2020 \text { (in } \\
\text { intervention group) }\end{array}$ & 7.8 & $-4.6,20.3$ \\
\hline $\begin{array}{l}\text { Average monthly change in number of new } \\
\text { FP acceptors from May 2018-Feb. } 2020 \text { (in } \\
\text { control group) }\end{array}$ & -1.5 & $-11.6,8.6$ \\
\hline Difference & 9.3 & $-6.7,25.4$ \\
\hline rho & 0.676 & \\
\hline Durbin-Watson statistic (original) & 0.653 & \\
\hline Durbin-Watson statistic (transformed) & 1.555 & \\
\hline
\end{tabular}

Note: ${ }^{+} p<.1 ; * p<.05 ; * * p<.01 ; * * * p<.001$; Source: Ghana DHIMS data, January 2017 to February 2020 


\subsubsection{Impact on New IUD and Implant Acceptors}

Table 9 presents results of the impact of OP cost removal for FP services only on new IUD and implants acceptors (intervention and control districts).

\section{New IUD Acceptors}

From Model M1 (Table 9) visualized in Figure 8, the intervention and control districts were significantly different at baseline. The trend over the pre-intervention period between the intervention and control districts was significantly different (Coef. $=-0.8$; C.I. $-1.4,-0.2$ ), indicating that the number of new IUD acceptors in the intervention districts was declining at a higher rate compared to the control districts. There was no statistically significant intervention effect during the first month of the intervention (Coef. = -3.6; C.I. $=-10.9$, 3.7). However, there was evidence of an increase during the intervention period in the intervention districts compared with that of the controls by 1.7 new IUD acceptors. Although not statistically significant, it appears that during the intervention period, the number of new IUD acceptors in the intervention districts increased at a rate of 0.8 per month. In the control districts however, the number of new IUD acceptors per month was decreasing by 0.1 per month though not significant. The results showed a noticeable significant difference between the intervention and control districts at baseline and the pre-intervention period, showing that uptake of IUD was significantly declining in the intervention districts. However, in the intervention period, there was an improvement in the uptake of IUD services, while uptake of IUD services trended downward.

\section{New Implant Acceptors}

From Model M2 on Table 9 (also see Figure 9), the results show no statistically significant difference in the number of new implant acceptors comparing the intervention with control districts. However, while the trend in the intervention districts was increasing at a rate of 1.4 per month during the intervention period (not significant), in the control districts, new implants acceptors were decreasing at a rate of 0.4 women per month (not significant). The intervention (OP cost removal only) did not appear to have improved the uptake of implants. 
TABLE 9: ITS parameter estimates for monthly new FP acceptors - five intervention and control districts

\begin{tabular}{|c|c|c|c|c|}
\hline & \multicolumn{2}{|c|}{ IUDs (M1) } & \multicolumn{2}{|c|}{ Implants (M2) } \\
\hline Variable & Coef. & 95\% C. I. & Coef. & 95\% C. I. \\
\hline $\begin{array}{l}\text { Number of new FP acceptors (in control } \\
\text { group) in Jan. } 2017\left(\beta_{0}\right)\end{array}$ & 1.7 & $-1.1,4.5$ & $167.0 * * *$ & $\begin{array}{l}136.9 \\
197.1\end{array}$ \\
\hline $\begin{array}{l}\text { Average monthly change in number of } \\
\text { new FP acceptors (in control group), Jan. } \\
2017-A p r .2018\left(\beta_{1}\right)\end{array}$ & 0.0 & $-0.2,0.3$ & $-2.6 *$ & $-5.0,-0.2$ \\
\hline $\begin{array}{l}\text { Change in level of FP acceptors (in } \\
\text { control group) in May } 2018\left(\beta_{2}\right)\end{array}$ & 0.3 & $-2.4,3.1$ & -0.9 & $-17.6,15.9$ \\
\hline $\begin{array}{l}\text { Change in trend in monthly number of FP } \\
\text { acceptors (in control group) between } \\
\text { Jan. 2017-Apr. } 2018 \text { compared to May } \\
\text { 2018-Feb. } 2020\left(\beta_{3}\right)\end{array}$ & -0.1 & $-0.4,0.2$ & 2.2 & $-1.0,5.4$ \\
\hline $\begin{array}{l}\text { Difference in number of new FP } \\
\text { acceptors between intervention and } \\
\text { control groups in Jan. } 2017\left(\beta_{4}\right)\end{array}$ & $18.7 * * *$ & $\begin{array}{l}14.0 \\
23.4\end{array}$ & $56.2+$ & $-3.2,115.5$ \\
\hline $\begin{array}{l}\text { Difference in trend in monthly number of } \\
\text { new FP acceptors between intervention } \\
\text { and control groups from Jan 2017-Apr. } \\
2020\left(\beta_{5}\right)\end{array}$ & $-0.8 * *$ & $-1.4,-0.2$ & 5.7 & $-2.1,13.5$ \\
\hline $\begin{array}{l}\text { Difference in the change in level of new } \\
\text { FP acceptors between intervention and } \\
\text { control groups in May } 2018\left(\beta_{6}\right)\end{array}$ & -3.6 & $\begin{array}{l}-10.9 \\
3.7\end{array}$ & -23.2 & $-79.6,33.2$ \\
\hline $\begin{array}{l}\text { Difference in change in trend in monthly } \\
\text { number of new FP acceptors between } \\
\text { treatment and control from Jan. 2017- } \\
\text { Apr. } 2018 \text { compared to May 2018-Feb. } \\
2020\left(\beta_{7}\right)\end{array}$ & $1.7 * * *$ & $0.9,2.5$ & -3.9 & $-14.9,7.1$ \\
\hline $\begin{array}{l}\text { Average monthly change in number of } \\
\text { new FP acceptors from May 2018-Feb. } \\
2020 \text { (in intervention group) }\end{array}$ & 0.8 & $0.4,1.2$ & 1.4 & $-2.6,5.5$ \\
\hline $\begin{array}{l}\text { Average monthly change in number of } \\
\text { new FP acceptors from May 2018-Feb. } \\
2020 \text { (in control group) }\end{array}$ & -0.1 & $-0.2,0.0$ & -0.4 & $-1.7,1.0$ \\
\hline Difference & 0.9 & $0.5,1.3$ & 1.8 & $-2.4,6.0$ \\
\hline rho & 0.529 & & 0.681 & \\
\hline Durbin-Watson statistic (original) & 1.026 & & 0.649 & \\
\hline Durbin-Watson statistic (transformed) & 1.724 & & 1.600 & \\
\hline
\end{tabular}

Note: ${ }^{+} p<.1 ; * p<.05 ; * * p<.01 ; * * * p<.001$; Source: Ghana DHIMS data, January 2017 to February 2020 


\subsubsection{Impact on new Injectable and Oral Contraceptive Acceptors}

Table 10 presents results of the impact of OP cost removal only on new injectable and oral contraceptive acceptors (intervention and control districts).

\section{New Injectable Acceptors}

Comparing the intervention and control districts (M1 on Table 10), prior to the intervention, the trends in the number of new injectable acceptors were declining in both the intervention and control districts. During the intervention period however, the number of new injectable acceptors in the intervention districts showed an upward trend, increasing at a rate of 4.5 new acceptors per month, while the control districts continued to decline at a rate of -0.6 new acceptors (not statistically significant) (Figure 10). There is some evidence, though not statistically significant to show that the intervention (OP cost removal only) did have a positive impact on injectable acceptors as there was noticeable improvement during the intervention period.
FIGURE 10: Trends in new Injectable acceptors (January 2017 - February 2020)

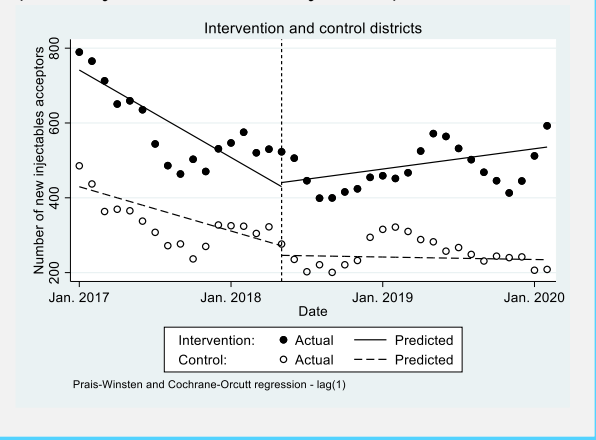

FIGURE 11: Trends in new oral contraceptive acceptors (January 2017 - February 2020)

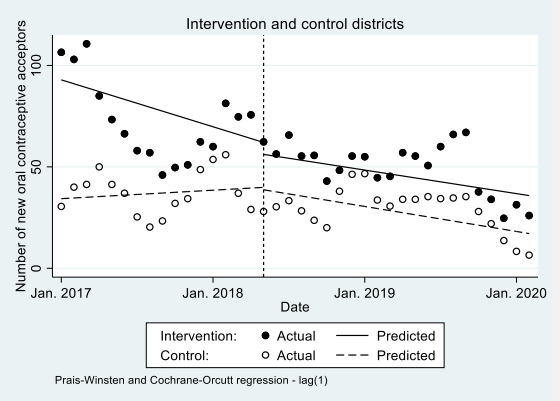

\section{New Oral Contraceptive Acceptors}

With respect to the number of new oral contraceptive acceptors, the intervention and control districts (M2 on Table 10), new oral contraceptive acceptors were not significantly different pre-and during the intervention period. However, it was observed that during the intervention period, the number of new oral contraceptive acceptors in both the intervention and control districts continued to decline although not statistically significant (Figure 11). 
TABLE 10: ITS parameter estimates for monthly new FP acceptors - five intervention and control districts

\begin{tabular}{|c|c|c|c|c|}
\hline \multirow[b]{2}{*}{ Variable } & \multicolumn{2}{|c|}{ Injectables } & \multicolumn{2}{|c|}{ Oral contraceptives } \\
\hline & Coef. & 95\% C. I. & Coef. & 95\% C. I. \\
\hline $\begin{array}{l}\text { Number of new FP acceptors (in control } \\
\text { group) in Jan. } 2017\left(\beta_{0}\right)\end{array}$ & $429.6 * * *$ & $\begin{array}{l}325.0 \\
534.2\end{array}$ & $34.3 * * *$ & $22.3,46.4$ \\
\hline $\begin{array}{l}\text { Average monthly change in number of } \\
\text { new FP acceptors (in control group), } \\
\text { Jan. 2017-Apr. } 2018\left(\beta_{1}\right)\end{array}$ & $-9.9 *$ & $-19.0,-0.8$ & 0.3 & $-1.5,2.2$ \\
\hline $\begin{array}{l}\text { Change in level of FP acceptors (in } \\
\text { control group) in May } 2018\left(\beta_{2}\right)\end{array}$ & -25.5 & $-57.0,6.0$ & -1.2 & $-13.2,10.8$ \\
\hline $\begin{array}{l}\text { Change in trend in monthly number of } \\
\text { FP acceptors (in control group) } \\
\text { between Jan. 2017-Apr. } 2018 \\
\text { compared to May 2018-Feb. } 2020\left(\beta_{3}\right)\end{array}$ & 9.3 & $-2.4,21.0$ & -1.4 & $-4.1,1.3$ \\
\hline $\begin{array}{l}\text { Difference in number of new FP } \\
\text { acceptors between intervention and } \\
\text { control groups in Jan. } 2017\left(\beta_{4}\right)\end{array}$ & $312.0 * * *$ & $\begin{array}{l}172.7 \\
451.2\end{array}$ & $58.6 * * *$ & $30.0,87.2$ \\
\hline $\begin{array}{l}\text { Difference in trend in monthly number } \\
\text { of new FP acceptors between } \\
\text { intervention and control groups from } \\
\text { Jan } 2017-A \text { pr. } 2020\left(\beta_{5}\right)\end{array}$ & -9.6 & $-23.4,4.2$ & -2.3 & $-5.4,0.8$ \\
\hline $\begin{array}{l}\text { Difference in the change in level of new } \\
\text { FP acceptors between intervention and } \\
\text { control groups in May } 2018\left(\beta_{6}\right)\end{array}$ & 36.5 & $\begin{array}{l}-31.0 \\
103.9\end{array}$ & -4.7 & $-21.8,12.4$ \\
\hline $\begin{array}{l}\text { Difference in change in trend in } \\
\text { monthly number of new FP acceptors } \\
\text { between treatment and control from } \\
\text { Jan. 2017-Apr. } 2018 \text { compared to May } \\
\text { 2018-Feb. } 2020\left(\beta_{7}\right)\end{array}$ & 14.7 & $-5.5,34.9$ & 2.3 & $-2.0,6.7$ \\
\hline $\begin{array}{l}\text { Average monthly change in number of } \\
\text { new FP acceptors from May 2018-Feb. } \\
2020 \text { (in intervention group) }\end{array}$ & 4.5 & $-3.9,12.9$ & -1.0 & $-2.5,0.6$ \\
\hline $\begin{array}{l}\text { Average monthly change in number of } \\
\text { new FP acceptors from May 2018-Feb. } \\
2020 \text { (in control group) }\end{array}$ & -0.6 & $-4.5,3.4$ & -1.0 & $-2.1,0.0$ \\
\hline Difference & 5.1 & $-4.2,14.4$ & 0.1 & $-1.8,1.9$ \\
\hline rho & 0.778 & & & 0.734 \\
\hline Durbin-Watson statistic (original) & 0.447 & & & 0.585 \\
\hline Durbin-Watson statistic (transformed) & 1.196 & & & 1.638 \\
\hline
\end{tabular}

Note: ${ }^{+} \mathrm{p}<.1 ; * \mathrm{p}<.05 ; * * \mathrm{p}<.01 ; * * * \mathrm{p}<.001$; Source: Ghana DHIMS data, January 2017 to February 2020 


\subsection{Impact of Out-of-Pocket Cost Removal for FP Services, Demand Generation, LARC Training on Uptake of FP and Method Mix (one district)}

This section examines the impact of OP cost removal for FP services, demand generation, and LARCs training on new FP, IUD, implant, injectable and oral contraceptive (unintended) acceptors. This involves only one intervention district where the three combinations of interventions were implemented compared with the corresponding control district.

\subsubsection{Impact on New FP acceptors}

Table 11 shows results of the impact of the three combinations of the interventions (OP cost removal for FP services, demand generation, and LARCs training) on new FP acceptors (intervention and control districts).

From Table 11 and Figure 12, the results show no evidence of a difference between the intervention and control districts with respect to the number of new FP acceptors during the pre-intervention period. However, the trend in the intervention

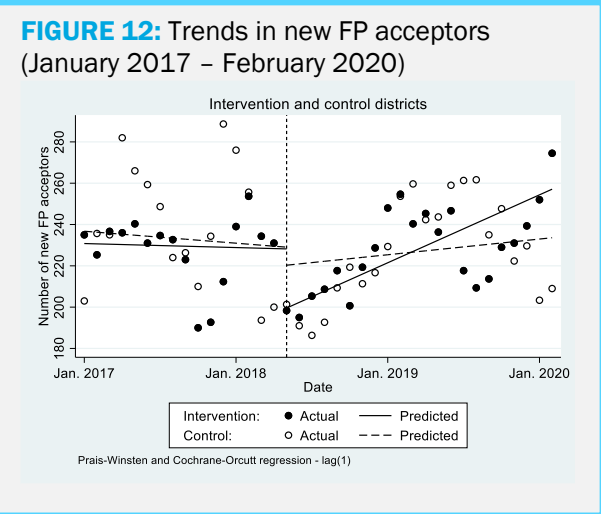
district was significantly increasing during the intervention period at a rate of about 2.7 (C.I. = 1.2, 4.3; p<0.001) new FP acceptors. In contrast, the increase in the control district, during the intervention period was marginal (Coef. $=0.6)$ and not significant. Although the intervention (OP cost removal for FP services, demand generation, and LARCs training) did not have an immediate effect, it significantly improved uptake of FP during the intervention period. 
TABLE 11: ITS parameter estimates for monthly new FP acceptors - one district

\begin{tabular}{|c|c|c|}
\hline Variable & New FP acceptors & $95 \%$ C. I. \\
\hline $\begin{array}{l}\text { Number of new FP acceptors (in control group) in Jan. } \\
2017\left(\beta_{0}\right)\end{array}$ & $236.8 * * *$ & $181.9,291.6$ \\
\hline $\begin{array}{l}\text { Average monthly change in number of new FP } \\
\text { acceptors (in control group), Jan. 2017-Apr. } 2018\left(\beta_{1}\right)\end{array}$ & -0.5 & $-6.6,5.6$ \\
\hline $\begin{array}{l}\text { Change in level of FP acceptors (in control group) in } \\
\text { May } 2018\left(\beta_{2}\right)\end{array}$ & -8.7 & $-47.0,29.6$ \\
\hline $\begin{array}{l}\text { Change in trend in monthly number of FP acceptors (in } \\
\text { control group) between Jan. 2017-Apr. } 2018 \text { compared } \\
\text { to May 2018-Feb. } 2020\left(\beta_{3}\right)\end{array}$ & 1.1 & $-6.6,8.8$ \\
\hline $\begin{array}{l}\text { Difference in number of new FP acceptors between } \\
\text { intervention and control groups in Jan. } 2017\left(\beta_{4}\right)\end{array}$ & -6.0 & $-62.1,50.1$ \\
\hline $\begin{array}{l}\text { Difference in trend in monthly number of new FP } \\
\text { acceptors between intervention and control groups } \\
\text { from Jan 2017-Apr. } 2020\left(\beta_{5}\right)\end{array}$ & 0.3 & $-6.1,6.8$ \\
\hline $\begin{array}{l}\text { Difference in the change in level of new FP acceptors } \\
\text { between intervention and control groups in May } 2018 \\
\left(\beta_{6}\right)\end{array}$ & -19.9 & $-62.8,23.0$ \\
\hline $\begin{array}{l}\text { Difference in change in trend in monthly number of new } \\
\text { FP acceptors between treatment and control from Jan. } \\
\text { 2017-Apr. } 2018 \text { compared to May 2018-Feb. } 2020\left(\beta_{7}\right)\end{array}$ & 1.8 & $-6.6,10.1$ \\
\hline $\begin{array}{l}\text { Average monthly change in number of new FP } \\
\text { acceptors from May 2018-Feb. } 2020 \text { (in intervention } \\
\text { group) }\end{array}$ & $2.7 * * *$ & $1.2,4.3$ \\
\hline $\begin{array}{l}\text { Average monthly change in number of new FP } \\
\text { acceptors from May 2018-Feb. } 2020 \text { (in control group) }\end{array}$ & 0.6 & $-1.8,3.0$ \\
\hline Difference & 2.1 & $-0.8,5.0$ \\
\hline rho & 0.634 & \\
\hline Durbin-Watson statistic (original) & 0.749 & \\
\hline Durbin-Watson statistic (transformed) & 1.626 & \\
\hline
\end{tabular}

Note: ${ }^{+} p<.1 ; * p<.05 ; * * p<.01 ; * * * p<.001$; Source: Ghana DHIMS data, January 2017 to February 2020 


\subsubsection{Impact on New IUD and Implant Acceptors}

Table 12 presents findings of the impact of the three combinations of interventions on new IUD and implant acceptors (intervention and control districts).

\section{New IUD Acceptors}

Comparing the intervention and control districts (M1 on Table 12), the number of new IUD acceptors was on the decrease in the intervention district and on the increase in the control district before the intervention. While there was no statistically significant effect of the intervention during the first month, there was a statistically significant increase in the number of new IUD acceptors in the intervention period in the intervention district compared with the control district (Coef. $=0.2 ;$ C.I. $=0.0,0.4 ; p<$ 0.05). After the intervention, new IUD acceptors in the intervention district increased monthly at a was statistically significant $(\mathrm{C} . \mathrm{I} .=0.1,0.3 ; p<0.01)$, while there was no noticeable increase in the control sites (Figure 13). The findings show evidence of improvement in new IUD acceptors as it improved significantly in the intervention period.

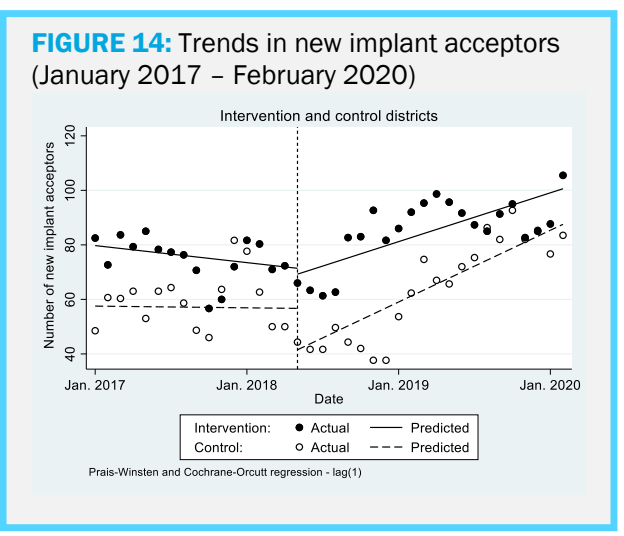

\section{New Implant Acceptors}

Results from Model M2 (Table 12), prior to the intervention, the number of new implants acceptors was on the increase in the control district and decreasing in the intervention district. Additionally, there was no statistically significant effect of the intervention during the first month. However, the results show that during the intervention period, the trend of new implants acceptors in the intervention district significantly increased monthly at a rate of 1.5 (C.I. = 0.6, 2.4; $\mathrm{p}<0.01)$ new acceptors and increased monthly at a rate of $2.2(\mathrm{C} . \mathrm{I} .=1.3,3.1 ; \mathrm{p}<.001)$ new acceptors in the control district (Figure 14). From the results, there is some evidence of improvement in the intervention district regarding the number of new implant acceptors as it improved from a declining pre-intervention trend to an increasing trend during the intervention period. 
TABLE 12: ITS parameter estimates for monthly new FP acceptors - one district

\begin{tabular}{|c|c|c|c|c|}
\hline & \multicolumn{2}{|c|}{ IUDs (M1) } & \multicolumn{2}{|c|}{ Implants (M2) } \\
\hline Variable & Coef. & 95\% C. I. & Coef. & 95\% C. I. \\
\hline $\begin{array}{l}\text { Number of new FP acceptors (in control } \\
\text { group) in Jan. } 2017\left(\beta_{0}\right)\end{array}$ & 0.4 & $-0.2,0.9$ & $57.5 * * *$ & $\begin{array}{c}44.4 \\
70 . \\
7\end{array}$ \\
\hline $\begin{array}{l}\text { Average monthly change in number of } \\
\text { new FP acceptors (in control group), Jan. } \\
\text { 2017-Apr. } 2018\left(\beta_{1}\right)\end{array}$ & 0.0 & $-0.1,0.1$ & -0.1 & $-1.7,1.6$ \\
\hline $\begin{array}{l}\text { Change in level of FP acceptors (in control } \\
\text { group) in May } 2018\left(\beta_{2}\right)\end{array}$ & -0.5 & $-1.6,0.6$ & $-15.2+$ & $-31.7,1.4$ \\
\hline $\begin{array}{l}\text { Change in trend in monthly number of FP } \\
\text { acceptors (in control group) between Jan. } \\
\text { 2017-Apr. } 2018 \text { compared to May 2018- } \\
\text { Feb. } 2020\left(\beta_{3}\right)\end{array}$ & 0.0 & $-0.2,0.1$ & $2.2 *$ & $0.2,4.3$ \\
\hline $\begin{array}{l}\text { Difference in number of new FP acceptors } \\
\text { between intervention and control groups } \\
\text { in Jan. } 2017\left(\beta_{4}\right)\end{array}$ & 0.4 & $-1.0,1.8$ & $22.2 * *$ & $\begin{array}{l}6.5 \\
37 . \\
9\end{array}$ \\
\hline $\begin{array}{l}\text { Difference in trend in monthly number of } \\
\text { new FP acceptors between intervention } \\
\text { and control groups from Jan 2017-Apr. } \\
2020\left(\beta_{5}\right)\end{array}$ & 0.0 & $-0.2,0.1$ & -0.5 & $-2.4,1.4$ \\
\hline $\begin{array}{l}\text { Difference in the change in level of new } \\
\text { FP acceptors between intervention and } \\
\text { control groups in May } 2018\left(\beta_{6}\right)\end{array}$ & 0.4 & $-1.0,1.8$ & 13.0 & $\begin{array}{l}-6.8 \\
32 \\
8\end{array}$ \\
\hline $\begin{array}{l}\text { Difference in change in trend in monthly } \\
\text { number of new FP acceptors between } \\
\text { treatment and control from Jan. 2017- } \\
\text { Apr. } 2018 \text { compared to May } 2018 \text {-Feb. } \\
2020\left(\beta_{7}\right)\end{array}$ & $0.2^{*}$ & $0.0,0.4$ & -0.2 & $-2.8,2.3$ \\
\hline $\begin{array}{l}\text { Average monthly change in number of } \\
\text { new FP acceptors from May 2018-Feb. } \\
2020 \text { (in intervention group) }\end{array}$ & $0.2 * *$ & $0.1,0.3$ & $1.5 * *$ & $0.6,2.4$ \\
\hline $\begin{array}{l}\text { Average monthly change in number of } \\
\text { new FP acceptors from May 2018-Feb. } \\
2020 \text { (in control group) }\end{array}$ & 0.0 & $0.0,0.0$ & $2.2 * \star \star$ & $1.3,3.1$ \\
\hline Difference & $0.2 * *$ & $0.1,0.3$ & -0.7 & $-1.9,0.5$ \\
\hline rho & 0.524 & & 0.552 & \\
\hline Durbin-Watson statistic (original) & 0.749 & & 0.994 & \\
\hline Durbin-Watson statistic (transformed) & 1.626 & & 1.651 & \\
\hline
\end{tabular}

Note: ${ }^{+} p<.1 ; * p<.05 ; * * p<.01 ; * * * p<.001$; Source: Ghana DHIMS data, January 2017 to February 2020 


\subsubsection{Impact on New Injectable and Oral Contraceptive Acceptors}

Table 13 shows findings of the impact of the three combinations of the interventions on new injectable and oral contraceptive acceptors (intervention and control districts).

\section{New Injectable Acceptors}

From Model M1 on Table 13, the intervention did not have a statistically significant effect on new injectable acceptors pre-and during the intervention, comparing the intervention and control districts. Although not significant, during the intervention period, the number of new injectable acceptors was increasing in the intervention district (Coef. = 1.0; C.I. = -0.1, 2.1; $p<0.1$ ) and continued to decline in the control district (Figure 15). In general, the intervention did not appear to have a significant impact on the number of new injectable acceptors.

\section{New Oral Contraceptive Acceptors}

The results show that in the pre-intervention period, the number of new oral contraceptive acceptors was on the decline in the intervention district and trending upwards in the control district (not significant). During the intervention period, the number of new oral contraceptive acceptors in the intervention district decreased at a rate of 0.1 acceptors per month (not significant). In the control district, the number of new oral contraceptive acceptors trended downwards, decreasing at a rate of 0.8 new acceptors per month (C.I. $=-1.7,0.1 ; p<0.1$ ) (Figure 16). Despite the intervention (OP cost removal for FP services, demand generation, and LARCs training), the number of new oral contraceptive acceptors trended downwards in the intervention and control districts.

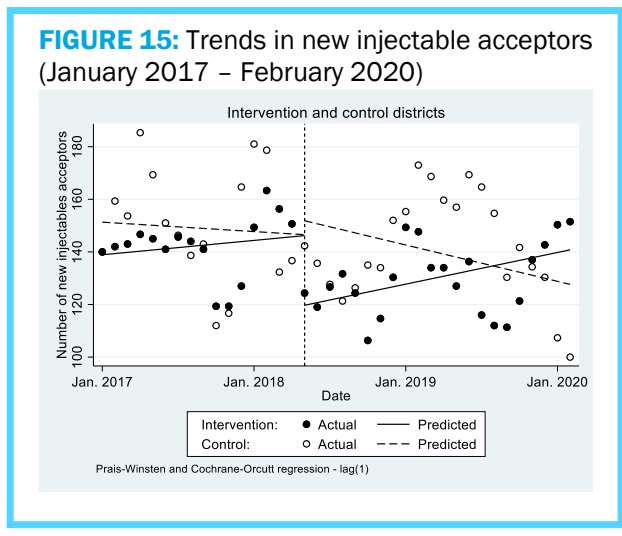

FIGURE 16: Trends in oral contraceptive acceptors (January 2017 - February 2020)

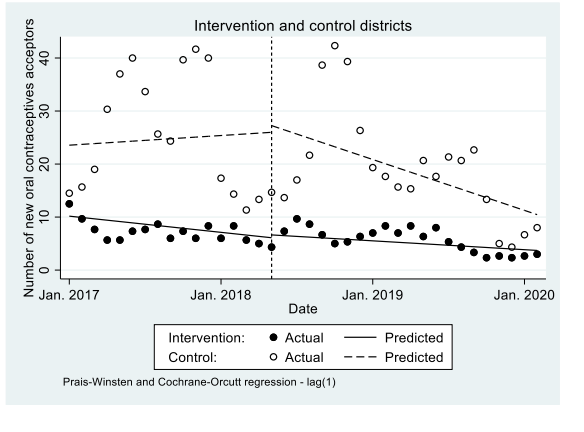


TABLE 13: ITS parameter estimates for monthly new FP acceptors - one district

\begin{tabular}{|c|c|c|c|c|}
\hline & \multicolumn{2}{|c|}{ Injectables (M1) } & \multicolumn{2}{|c|}{ Oral contraceptives (M2) } \\
\hline Variable & Coef. & 95\% C.I. & Coef. & 95\% C.I. \\
\hline $\begin{array}{l}\text { Number of new FP acceptors (in } \\
\left.\text { control group) in Jan. } 2017 \text { ( } \beta_{0}\right)\end{array}$ & $151.3 * * *$ & $124.1,178.5$ & $23.6 * *$ & $\begin{array}{l}7.5 \\
39 . \\
7\end{array}$ \\
\hline $\begin{array}{l}\text { Average monthly change in number } \\
\text { of new FP acceptors (in control } \\
\text { group), Jan. 2017-Apr. } 2018\left(\beta_{1}\right)\end{array}$ & -0.3 & $-4.1,3.5$ & 0.2 & $-1.7,2.0$ \\
\hline $\begin{array}{l}\text { Change in level of FP acceptors (in } \\
\text { control group) in May } 2018\left(\beta_{2}\right)\end{array}$ & 5.3 & $-23.2,33.9$ & 1.3 & $\begin{array}{c}-11.0 \\
13 . \\
5\end{array}$ \\
\hline $\begin{array}{l}\text { Change in trend in monthly number } \\
\text { of FP acceptors (in control group) } \\
\text { between Jan. 2017-Apr. } 2018 \\
\text { compared to May 2018-Feb. } 2020 \\
\left(\beta_{3}\right)\end{array}$ & -0.9 & $-6.0,4.3$ & -1.0 & $-3.5,1.6$ \\
\hline $\begin{array}{l}\text { Difference in number of new FP } \\
\text { acceptors between intervention and } \\
\text { control groups in Jan. } 2017\left(\beta_{4}\right)\end{array}$ & -12.4 & $-40.2,15.4$ & -13.4 & $-30.0,3.3$ \\
\hline $\begin{array}{l}\text { Difference in trend in monthly } \\
\text { number of new FP acceptors } \\
\text { between intervention and control } \\
\text { groups from Jan 2017-Apr. } 2020 \\
\left(\beta_{5}\right)\end{array}$ & 0.8 & $-3.3,4.8$ & -0.4 & $-2.3,1.5$ \\
\hline $\begin{array}{l}\text { Difference in the change in level of } \\
\text { new FP acceptors between } \\
\text { intervention and control groups in } \\
\text { May } 2018\left(\beta_{6}\right)\end{array}$ & -31.8 & $-63.4,-0.2$ & -0.7 & $\begin{array}{c}-13.4 \\
11 \\
9\end{array}$ \\
\hline $\begin{array}{l}\text { Difference in change in trend in } \\
\text { monthly number of new FP } \\
\text { acceptors between treatment and } \\
\text { control from Jan. 2017-Apr. } 2018 \\
\text { compared to May 2018-Feb. } 2020 \\
\left(\beta_{7}\right)\end{array}$ & 1.4 & $-4.2,7.0$ & 1.1 & $-1.6,3.7$ \\
\hline $\begin{array}{l}\text { Average monthly change in number } \\
\text { of new FP acceptors from May } \\
\text { 2018-Feb. } 2020 \text { (in intervention } \\
\text { group) }\end{array}$ & $1.0+$ & $-0.1,2.1$ & -0.1 & $-0.4,0.1$ \\
\hline $\begin{array}{l}\text { Average monthly change in number } \\
\text { of new FP acceptors from May } \\
\text { 2018-Feb. } 2020 \text { (in control group) }\end{array}$ & -1.2 & $-3.1,0.8$ & $-0.8+$ & $-1.7,0.1$ \\
\hline Difference & $2.2+$ & $-0.1,4.4$ & 0.7 & $-0.3,1.6$ \\
\hline rho & 0.641 & & 0.721 & \\
\hline Durbin-Watson statistic (original) & 0.697 & & 0.556 & \\
\hline $\begin{array}{l}\text { Durbin-Watson statistic } \\
\text { (transformed) }\end{array}$ & 1.530 & & 1.246 & \\
\hline
\end{tabular}


Note: $+p<.1 ; * p<.05 ; * * p<.01 ; * * * p<.001$; Source: Ghana DHIMS data, January 2017 to February 2020

\subsection{Impact of Out-of-Pocket Cost Removal for FP Services and LARCs Training on Uptake of FP and Method Mix (one district)}

This section examines the impact of OP cost removal for FP services and LARCs training on new FP, IUD, implant, injectable, and oral contraceptive (unintended) acceptors. This involves only one intervention district where OP cost removal for FP services and LARCs training was implemented compared with the corresponding control district.

\subsubsection{Impact on New FP Acceptors}

Table 14 presents results of the impact of the two combinations of the interventions (OP cost removal for FP services and LARCs training) on new FP acceptors intervention and control districts).

\section{New FP Acceptors}

From Table 14 and Figure 17, there was a statistically significant positive effect of the intervention on the number of new FP acceptors during the first month of the intervention (Coef. = 26.9; C.I. = 1.1, 52.6; $p<.05)$. However, the

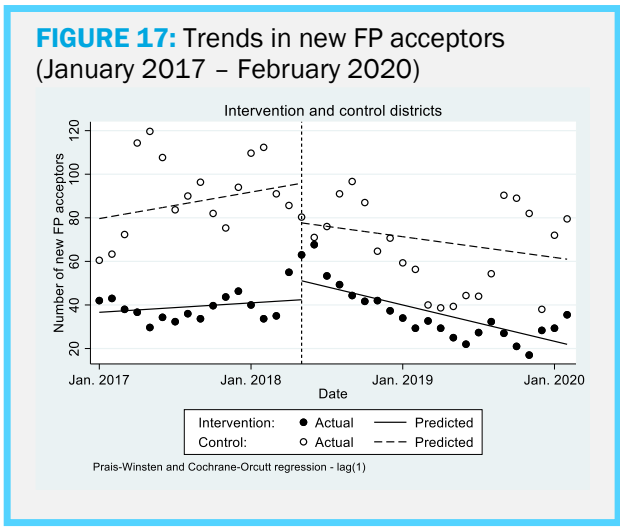
results further show that during the intervention period, the number of new acceptors in the intervention district decreased at a rate of 1.4 new acceptors per month (C.I. -2.3, $0.5 ; p<.01$ ). Although there was a similar decline in the control district, it was not statistically significant. The findings seem to suggest that in the first month of the intervention, there was a significant improvement in FP uptake and subsequently declined. This will require further investigation to better understand what may have caused the number of new FP acceptors to decline during the intervention period. 
TABLE 14: ITS parameter estimates for monthly new FP acceptors - one district

\begin{tabular}{|c|c|c|}
\hline Variable & $\begin{array}{l}\text { New FP } \\
\text { acceptors }\end{array}$ & $95 \%$ C. I. \\
\hline $\begin{array}{l}\text { Number of new FP acceptors (in control group) in Jan. } \\
2017\left(\beta_{0}\right)\end{array}$ & $79.6 * * *$ & $48.4,110.9$ \\
\hline $\begin{array}{l}\text { Average monthly change in number of new FP } \\
\text { acceptors (in control group), Jan. 2017-Apr. } 2018\left(\beta_{1}\right)\end{array}$ & 1.0 & $-1.8,3.9$ \\
\hline $\begin{array}{l}\text { Change in level of FP acceptors (in control group) in } \\
\text { May } 2018\left(\beta_{2}\right)\end{array}$ & $-18.2+$ & $-39.9,3.5$ \\
\hline $\begin{array}{l}\text { Change in trend in monthly number of FP acceptors (in } \\
\text { control group) between Jan. 2017-Apr. } 2018 \text { compared } \\
\left.\text { to May 2018-Feb. } 2020 \text { ( } \beta_{3}\right)\end{array}$ & -1.8 & $-5.8,2.2$ \\
\hline $\begin{array}{l}\text { Difference in number of new FP acceptors between } \\
\text { intervention and control groups in Jan. } 2017\left(\beta_{4}\right)\end{array}$ & $-43.0 *$ & $-75.7,-10.3$ \\
\hline $\begin{array}{l}\text { Difference in trend in monthly number of new FP } \\
\text { acceptors between intervention and control groups } \\
\text { from Jan 2017-Apr. } 2020\left(\beta_{5}\right)\end{array}$ & -0.7 & $-3.9,2.5$ \\
\hline $\begin{array}{l}\text { Difference in the change in level of new FP acceptors } \\
\text { between intervention and control groups in May } 2018 \\
\left(\beta_{6}\right)\end{array}$ & $26.9 *$ & $1.1,52.6$ \\
\hline $\begin{array}{l}\text { Difference in change in trend in monthly number of new } \\
\text { FP acceptors between treatment and control from Jan. } \\
\text { 2017-Apr. } 2018 \text { compared to May 2018-Feb. } 2020\left(\beta_{7}\right)\end{array}$ & 0.1 & $-4.4,4.5$ \\
\hline $\begin{array}{l}\text { Average monthly change in number of new FP } \\
\text { acceptors from May 2018-Feb. } 2020 \text { (in intervention } \\
\text { group) }\end{array}$ & $-1.4 * *$ & $-2.3,-0.5$ \\
\hline $\begin{array}{l}\text { Average monthly change in number of new FP } \\
\text { acceptors from May 2018-Feb. } 2020 \text { (in control group) }\end{array}$ & -0.8 & $-3.0,1.4$ \\
\hline Difference & -0.6 & $-3.0,1.8$ \\
\hline rho & 0.570 & \\
\hline Durbin-Watson statistic (original) & 0.845 & \\
\hline Durbin-Watson statistic (transformed) & 1.570 & \\
\hline
\end{tabular}

Note: ${ }^{+} \mathrm{p}<.1 ; * \mathrm{p}<.05 ; * * \mathrm{p}<.01 ; * * * \mathrm{p}<.001$; Source: Ghana DHIMS data, January 2017 to February 2020 


\subsubsection{Impact on New IUD and Implant Acceptors}

Table 15 shows findings of the impact of the two combinations of the interventions (OP cost removal for FP services and LARCs training) on new IUD and implant acceptors (intervention and control districts).

\section{New IUD Acceptors}

Model M2 on Table 15 shows that the interventions did not have a significant effect on new IUD acceptors when the intervention district was compared with the control district (Figure 18). During the intervention, while the number of new IUD acceptors was decreasing significantly at a rate of 0.1 (C.I. $=-0.2,0.0)$ per month in the control district, there was no statistically significant change in the intervention district.

\section{New Implants Acceptors}

Comparing the intervention and control districts (M2 on Table 15), There was a statistically significant difference between the intervention and control districts at baseline with the control district doing better (Coef. $=-29.0$; C.I. $=-56.2$, 1.8). The results show no evidence of positive intervention effect during the first month (May 2018) of the intervention. However, during the intervention period, the number of new implant acceptors in the intervention district significantly decreased at a rate of 1.3 (C.I. $=-1.9,-0.7 ; p$ $<0.001$ ), while in the control district the number of implant acceptors decreased by 0.5 (C.I. $=-1.0,0.1 ; p<0.001$ ) per month (Figure 19). This requires further investigation to understand the decline in the number of new implant acceptors during the intervention period.
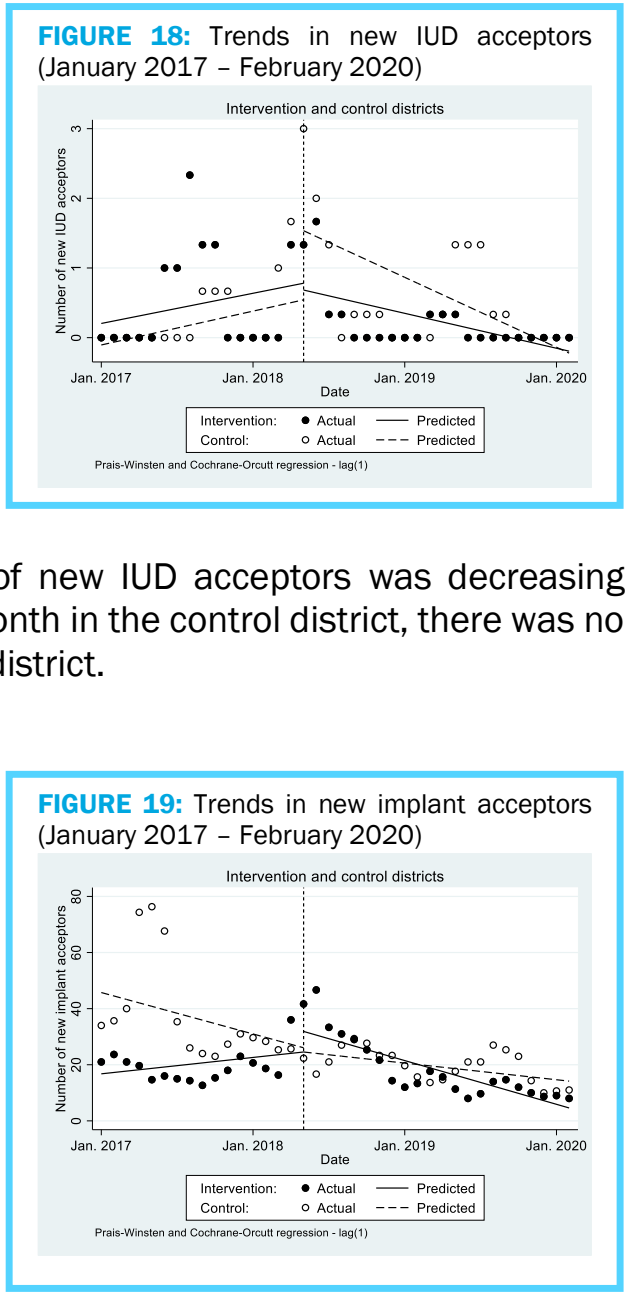

FIGURE 19: Trends in new implant acceptors (January 2017 - February 2020) 
TABLE 15: Parameter estimates for monthly new FP acceptors - one district

\begin{tabular}{|c|c|c|c|c|}
\hline & \multicolumn{2}{|c|}{ IUDs (M1) } & \multicolumn{2}{|c|}{ Implants (M2) } \\
\hline Variable & Coef. & 95\% C.I. & Coef. & 95\% C.I. \\
\hline $\begin{array}{l}\text { Number of new FP acceptors (in control } \\
\text { group) in Jan. } 2017\left(\beta_{0}\right)\end{array}$ & -0.1 & $-0.5,0.3$ & $45.7 * *$ & $20.1,71.4$ \\
\hline $\begin{array}{l}\text { Average monthly change in number of } \\
\text { new FP acceptors (in control group), Jan. } \\
\text { 2017-Apr. } 2018\left(\beta_{1}\right)\end{array}$ & 0.0 & $-0.1,0.1$ & -1.2 & $-2.9,0.5$ \\
\hline $\begin{array}{l}\text { Change in level of FP acceptors (in control } \\
\text { group) in May } 2018\left(\beta_{2}\right)\end{array}$ & 1.0 & $-0.4,2.4$ & -1.5 & $-8.2,5.1$ \\
\hline $\begin{array}{l}\text { Change in trend in monthly number of FP } \\
\text { acceptors (in control group) between Jan. } \\
2017-A p r .2018 \text { compared to May 2018- } \\
\text { Feb. } 2020\left(\beta_{3}\right)\end{array}$ & $-0.1+$ & $-0.3,0.0$ & 0.7 & $-1.1,2.6$ \\
\hline $\begin{array}{l}\text { Difference in number of new FP acceptors } \\
\text { between intervention and control groups } \\
\text { in Jan. } 2017\left(\beta_{4}\right)\end{array}$ & 0.3 & $-0.5,1.1$ & $-29.0 *$ & $-56.2,-1.8$ \\
\hline $\begin{array}{l}\text { Difference in trend in monthly number of } \\
\text { new FP acceptors between intervention } \\
\text { and control groups from Jan 2017-Apr. } \\
2020\left(\beta_{5}\right)\end{array}$ & 0.0 & $-0.1,0.1$ & 1.7 & $-0.6,4.0$ \\
\hline $\begin{array}{l}\text { Difference in the change in level of new } \\
\text { FP acceptors between intervention and } \\
\left.\text { control groups in May } 2018 \text { ( } \beta_{6}\right)\end{array}$ & -1.1 & $-2.8,0.6$ & 8.8 & $-3.8,21.4$ \\
\hline $\begin{array}{l}\text { Difference in change in trend in monthly } \\
\text { number of new FP acceptors between } \\
\text { treatment and control from Jan. 2017- } \\
\text { Apr. } 2018 \text { compared to May 2018-Feb. } \\
2020\left(\beta_{7}\right)\end{array}$ & 0.0 & $-0.2,0.3$ & $-2.5+$ & $-5.3,0.2$ \\
\hline $\begin{array}{l}\text { Average monthly change in number of } \\
\text { new FP acceptors from May 2018-Feb. } \\
2020 \text { (in intervention group) }\end{array}$ & 0.0 & $-0.1,0.0$ & $-1.3 * * *$ & $-1.9,-0.7$ \\
\hline $\begin{array}{l}\text { Average monthly change in number of } \\
\text { new FP acceptors from May 2018-Feb. } \\
2020 \text { (in control group) }\end{array}$ & $-0.1 *$ & $-0.2,0.0$ & $-0.5+$ & $-1.0,0.1$ \\
\hline Difference & 0.0 & $-0.1,0.1$ & $-0.8+$ & $-1.6,0.0$ \\
\hline rho & 0.658 & & 0.661 & \\
\hline Durbin-Watson statistic (original) & 0.744 & & 0.702 & \\
\hline Durbin-Watson statistic (transformed) & 1.734 & & 1.345 & \\
\hline
\end{tabular}

Note: ${ }^{+} p<.1 ; * p<.05 ; * * p<.01 ; * * * p<.001$; Source: Ghana DHIMS data, January 2017 to February 2020 


\subsubsection{Impact on New Injectables and Oral Contraceptive Acceptors}

Table 16 presents findings of the impact of the two combinations of the interventions (OP cost removal for FP services and LARCs training) on new injectable and oral contraceptive (unintended) acceptors (intervention and control districts).

\section{New Injectables Acceptors}

Comparing the intervention and control districts (M1 on Table 16), there was a statistically significant difference between the intervention and control districts at baseline (Coef. $=-5.4 ; \mathrm{C}$. I. $=-8.9,-0.2 ; p<0.01)$. Before the intervention, there was also a statistically significant difference between the slope of the intervention and control districts, with the control district having a higher number of new injectables acceptors (Coef. = 0.9 ; C.I. $=-1.6,-0.2 ; p<0.01)$. The results showed evidence of positive intervention effect during the first month (May 2018) of the intervention (Coef. $=9.3$; C.I. $=1.4,17.2 ; \mathrm{p}<$ 0.05). During the intervention period, the number of new injectables acceptors in the intervention district significantly decreased at a rate of 0.5 new injectables acceptors per month (C.I. $=-0.8$, $-0.2 ; p<0.05)$. Although the number of new injectable acceptors in the control district was also decreasing but not significantly (Figure 20). While the intervention appeared to have a significant effect in the first month of the intervention, it declined thereafter, which requires further investigation to understand the decrease in trend.

\section{New Oral Contraceptive Acceptors}

From Model M2 on Table 16, the results show that the intervention did not have any unintended significant impact on the number of new oral contraceptive acceptors comparing the intervention to the control districts (Figure 21).
FIGURE 20: Trends in new injectable acceptors (January 2017 - February 2020)

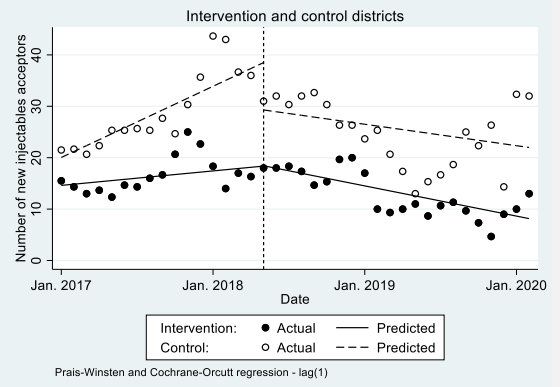

FIGURE 21: Trends in new oral contraceptive acceptors (January 2017 - February 2020)

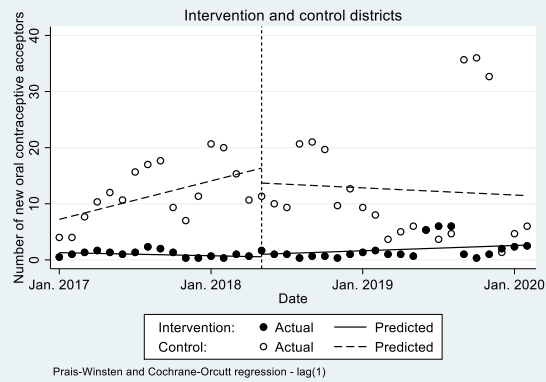


TABLE 16: Parameter estimates for monthly new FP acceptors - one district

\begin{tabular}{|c|c|c|c|c|}
\hline \multirow[b]{2}{*}{ Variable } & \multicolumn{2}{|c|}{ Injectables (M1) } & \multicolumn{2}{|c|}{$\begin{array}{l}\text { Oral contraceptives } \\
\text { (M2) }\end{array}$} \\
\hline & Coef. & 95\% C. I. & Coef. & 95\% C. I. \\
\hline $\begin{array}{l}\text { Number of new FP acceptors (in control } \\
\left.\text { group) in Jan. } 2017 \text { ( } \beta_{0}\right)\end{array}$ & $20.0 * * *$ & $17.3,22.8$ & $7.2 * *$ & $\begin{array}{c}2.5 \\
12 . \\
0\end{array}$ \\
\hline $\begin{array}{l}\text { Average monthly change in number of } \\
\text { new FP acceptors (in control group), } \\
\text { Jan. 2017-Apr. } 2018\left(\beta_{1}\right)\end{array}$ & $1.2 * * *$ & $0.6,1.7$ & $0.6+$ & $-0.1,1.3$ \\
\hline $\begin{array}{l}\text { Change in level of FP acceptors (in } \\
\text { control group) in May } 2018\left(\beta_{2}\right)\end{array}$ & $-9.2 * *$ & $-16.1,-2.4$ & -2.7 & $-10.1,4.8$ \\
\hline $\begin{array}{l}\text { Change in trend in monthly number of } \\
\text { FP acceptors (in control group) between } \\
\text { Jan. 2017-Apr. } 2018 \text { compared to May } \\
\text { 2018-Feb. } 2020\left(\beta_{3}\right)\end{array}$ & $-1.5 * *$ & $-2.6,-0.4$ & -0.7 & $-2.2,0.8$ \\
\hline $\begin{array}{l}\text { Difference in number of new FP } \\
\text { acceptors between intervention and } \\
\text { control groups in Jan. } 2017\left(\beta_{4}\right)\end{array}$ & $-5.4 * \star$ & $-8.9,-2.0$ & $-5.9 *$ & $\begin{array}{c}-10.8,- \\
1.1\end{array}$ \\
\hline $\begin{array}{l}\text { Difference in trend in monthly number } \\
\text { of new FP acceptors between } \\
\text { intervention and control groups from } \\
\text { Jan 2017-Apr. } 2020\left(\beta_{5}\right)\end{array}$ & $-0.9 * *$ & $-1.6,-0.2$ & $-0.6+$ & $-1.3,0.1$ \\
\hline $\begin{array}{l}\text { Difference in the change in level of new } \\
\text { FP acceptors between intervention and } \\
\text { control groups in May } 2018\left(\beta_{6}\right)\end{array}$ & $9.3 *$ & $1.4,17.2$ & 3.1 & $-4.4,10.7$ \\
\hline $\begin{array}{l}\text { Difference in change in trend in monthly } \\
\text { number of new FP acceptors between } \\
\text { treatment and control from Jan. 2017- } \\
\text { Apr. } 2018 \text { compared to May } 2018 \text {-Feb. } \\
2020\left(\beta_{7}\right)\end{array}$ & 0.8 & $-0.5,2.0$ & 0.8 & $-0.7,2.3$ \\
\hline $\begin{array}{l}\text { Average monthly change in number of } \\
\text { new FP acceptors from May 2018-Feb. } \\
2020 \text { (in intervention group) }\end{array}$ & $-0.5 * *$ & $-0.8,-0.2$ & 0.1 & $0.0,0.2$ \\
\hline $\begin{array}{l}\text { Average monthly change in number of } \\
\text { new FP acceptors from May 2018-Feb. } \\
2020 \text { (in control group) }\end{array}$ & -0.3 & $-1.1,0.4$ & -0.1 & $-1.2,1.0$ \\
\hline Difference & -0.1 & $-1.0,0.7$ & 0.2 & $-0.9,1.3$ \\
\hline rho & 0.545 & & 0.512 & \\
\hline Durbin-Watson statistic (original) & 0.872 & & 0.979 & \\
\hline Durbin-Watson statistic (transformed) & 1.785 & & 1.613 & \\
\hline
\end{tabular}

Note: ${ }^{+} p<.1 ; * p<.05 ; * * p<.01 ; * * * p<.001$; Source: Ghana DHIMS data, January 2017 to February 2020 
The evaluation assessed the impact of the various combinations of interventions that were implemented on the number of new FP acceptors and method-specific new FP acceptors. The combinations of interventions considered in this analysis were:

i. OP cost removal for FP services + other intervention (all seven intervention districts with OP cost removal for FP services);

vi. OP cost removal for FP services only (five intervention districts);

vii. OP cost removal for FP services + demand generation + LARCs training (one intervention district); and

viii. OP cost removal for FP services + LARCs training (one intervention district).

Findings from the ITS analyses show that three of the four combinations of interventions, in general, appeared to have positive impacts on uptake of FP services and method mix. Except for OP cost removal for FP services and LARCs training only (without demand generation) combination of the intervention, all the other combinations showed positive impacts on the overall uptake of FP services as well as on method-specific uptake. There was also evidence of an increase in the use LARCs and a decrease in the use of shortterm methods. The relative weakness of OP cost removal and LARC Training as an intervention needs to be investigated further.

Summary table of the impact of the combinations of interventions on the various FP indicators

\begin{tabular}{|c|c|c|c|c|}
\hline Indicator & $\begin{array}{l}\text { OP cost } \\
\text { removal and } \\
\text { other } \\
\text { interventions } \\
\text { (all seven } \\
\text { intervention } \\
\text { districts with } \\
\text { OP cost } \\
\text { removal) }\end{array}$ & $\begin{array}{l}\text { OP cost } \\
\text { removal only }\end{array}$ & $\begin{array}{l}\text { OP cost } \\
\text { removal for FP } \\
\text { services, } \\
\text { demand } \\
\text { generation, } \\
\text { and LARCs } \\
\text { training }\end{array}$ & $\begin{array}{l}\text { OP cost } \\
\text { removal and } \\
\text { LARCs } \\
\text { training }\end{array}$ \\
\hline New FP acceptors & Positive impact & $\begin{array}{l}\text { Positive } \\
\text { impact }\end{array}$ & $\begin{array}{l}\text { Positive } \\
\text { impact+ }\end{array}$ & $\begin{array}{l}\text { No positive } \\
\text { impact }\end{array}$ \\
\hline $\begin{array}{l}\text { New IUD } \\
\text { acceptors }\end{array}$ & $\begin{array}{l}\text { Positive } \\
\text { impact+ }\end{array}$ & $\begin{array}{l}\text { Positive } \\
\text { impact+ }\end{array}$ & $\begin{array}{l}\text { Positive } \\
\text { impact+ }\end{array}$ & $\begin{array}{l}\text { No positive } \\
\text { impact }\end{array}$ \\
\hline $\begin{array}{l}\text { New implant } \\
\text { acceptors }\end{array}$ & Positive impact & $\begin{array}{l}\text { Positive } \\
\text { impact }\end{array}$ & $\begin{array}{l}\text { Positive } \\
\text { impact+ }\end{array}$ & $\begin{array}{l}\text { No positive } \\
\text { impact }\end{array}$ \\
\hline New injectable & $\begin{array}{l}\text { Positive } \\
\text { impact+ }\end{array}$ & $\begin{array}{l}\text { Positive } \\
\text { impact }\end{array}$ & $\begin{array}{l}\text { Positive } \\
\text { impact+ }\end{array}$ & $\begin{array}{l}\text { No positive } \\
\text { impact }\end{array}$ \\
\hline $\begin{array}{l}\text { New oral } \\
\text { contraceptive }\end{array}$ & $\begin{array}{l}\text { No positive } \\
\text { impact }\end{array}$ & $\begin{array}{l}\text { No positive } \\
\text { impact }\end{array}$ & $\begin{array}{l}\text { No positive } \\
\text { impact }\end{array}$ & $\begin{array}{l}\text { Positive } \\
\text { impact }\end{array}$ \\
\hline
\end{tabular}

Note: + = Significant; \# examined whether the intervention(s) had unintended effects on uptake of oral contraceptives 


\subsection{Conclusion}

This report presents an evaluation of the impact of the various combination of FP Pilot intervention on FP service uptake and methods. Generally, the various combinations of interventions appeared to lead to an increase in the uptake of new FP acceptors. Although not statistically significant in some cases, it showed positive impacts in the first month of the intervention and/or an increase in the number of new FP acceptors during the intervention period compared to the pre-intervention period in the intervention district(s) relative to the control district(s). In some cases, the results showed that the interventions had a positive effect after the introduction of the intervention comparing the intervention to the control districts.

However, there was no surge in uptake of contraceptives immediately after cost removal. The increases were gradual and progressive. In effect, cost removal did not result in a spike in service utilization that could potentially overwhelm the health system, as was initially feared. This implies that cost and other resources could be planned accordingly to expect a gradual increase in contraceptive use.

Further, there was evidence of the effect of the intervention showing an increase in the number of new long-term methods acceptors, especially IUDs, and a decline in the use of oral contraceptives, one of the most popular short-term methods. Overall, there appeared to be a sustained decline in the use of short-term methods as more and more women opted for long-term methods, mainly IUD. The need to expand the number of providers with skills to provide long-term methods becomes critical.

\subsection{Recommendations}

Based on the findings of the study, the following recommendations are made:

- The Ministry of Health in collaboration with the National Health Insurance Authority and Ghana Health Service should strongly consider implementing the OP cost removal for FP services as it generally increases the total number of new FP acceptors and new LARC acceptors.

- The minimum package for the scale-up should be OP cost removal for FP services plus demand generation activities based on the statistically significant effect of OP cost removal for FP services on the number of new FP acceptors and LARCs acceptors.

- The Ministry of Health in collaboration with the National Health Insurance Authority and Ghana Health Service should consider undertaking a needs assessment regarding the capacity building of health providers for the provision of LARCs as the findings showed an increase in the use of LARCs before scale-up.

- The Ministry of Health and Ghana Health Service should ensure FP commodity security especially LARCs as there was evidence of an increase in LARCs acceptors. 